\title{
Teftâzânî'nin Düşünce Sisteminde İnsanî Nefsin Varlığı ve Hakikati
}

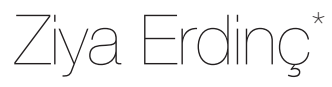

Öz

İnsanî nefsin mahiyeti/hakikati sorunu, İslâm düşüncesinde farklı yönleriyle inceleme konusu olmuş ve âlimler tarafından çeşitli yaklaşımlar ileri sürülmüştür. Mütekaddimîn kelamcılarının aksine müteahhirîn kelâmcıları takip ettikleri yöntem ve telif üslubu gibi sebeplerden dolayı genelde nefsin mahiyetini tartıştıkları bölümde görüşlerini açıkça belirtmemişlerdir. Müteahhirîn döneminin önde gelen kelamcılarından Teftâzânî de eserlerinin nefisle ilgili bölümlerinde, bir taraftan cismânî nefis görüşünü benimsediğini gösteren ifadeler kullanırken diğer taraftan soyut nefse kapı aralayan açıllamalara da yer vermiştir. Konuyla ilgili görüşünü tam olarak tespit etmek için düşünce sistemini meydana getiren diğer konulardaki görüşlerinin incelenmesi gerekir. Düşünce sistemi bir bütün olarak incelendiğinde Teftâzânî’nin, duyumsanan bedenin ötesinde bir nefsin varlığının apaçılığını savunduğu ve farklı cismânî nefis anlayışları arasından "diğer cisimlerle aynı hakikate sahip latif cisim” görüşünü tercih ettiği sonucuna ulaşılmıştır. Ayrıca onun, insanî nefsin hakikati konusunda kelâmcıların çoğunluğuna nispet ettiği aslî parçaları da insanî nefsin değil bedenin özü olarak kabul ettiği belirlenmiştir.

Bu çalışmada Teftâzânînin fizik, epistemoloji, ontoloji ve teoloji konularına ilişkin görüşlerinde insan tasavvurunun izleri takip edilecek ve elde edilen verilerden hareketle onun insanî nefsin hakikatine dair yaklaşımı ortaya konulacaktır.

Anahtar Kelimeler: Nefsin hakikati, Nefsin varlı̆̆ı, Latif cisim, Aslî parçalar, Soyut nefis, Teftâzânînin düşünce sistemi

\section{The Being and Essence of The Human Soul in al-Taftāzānīs Thought System}

Abstract: In Islamic thought, the question of the human soul's essence was examined with its different aspects and diverse approaches were presented by scholars. Unlike the earlier Islamic theologians (al-mutaqaddimūn), the later Islamic theologians (al-muta akhkhirün) in general have not explicitly expressed their opinions on the essence of the human soul throughout the chapter in which this problem was discussed. Because they had a distinctive method and discussion style that pertained to works in that period. In various chapters about human soul in al-Taftāzāni’s -one of the the foremost Islamic theologians of the later period of kalām-books, indication to admitting the concept of corporeal soul can be found. However, on the other hand, he has included clauses implying the idea of the immaterial soul in the same chapters. It is essential to analyze Taftāzānī`s opinions about the varied topics of which his thought system has consisted so as to determine his views on the essence of the human soul. By examining his thought system, this article has concluded that Taftāzānī has argued that there is self-evidently a human soul beyond this perceptible body, and he has preferred 'subtle body identical to other bodies in terms of the essence`among corporeal soul concepts. Moreover, he has considered essential parts (al-ajzā`al-așliyya), -a concept he predicated to most Islamic theologians- as a view on the essence of the human soul, not to be the essence of the human soul but the basis of the body.

This article traces Taftāzānī`s thought of the human soul through his views on physics, epistemology, ontology, and theology. Then, based on achieved findings, it reveals his opinion on the essence of the human soul.

Keywords: The essence of human soul, The being of human soul, The subtle body, The essential parts, The immaterial human soul, al-Taftāzānī`s thought system

* $\quad$ Dr. Öğretim Üyesi, Sakarya Üniversitesi İlahiyat Fakültesi, Kelam Anabilim Dalı.

İletişim: zerdinc@sakarya.edu.tr. Bu çalışma 2019 tarihinde Sakarya Üniversitesi Sosyal Bilimler Enstitüsü'nde tamamlanan “Teftâzânîde Bilgi Teorisi” başlıklı doktora tezinden faydalanılarak hazırlanmıştır. Danışmanlıklarından ötürü Prof. Dr. Ramazan Biçer ve Prof. Dr. Robert Wisnovsky’ye, destekleri dolayısıyla TÜBİTAK ve İSAM’a teşekkür ediyorum. 


\section{Giriş}

İnsanın hakikatinin ne olduğu meselesi her dönem kelâmcıların araştırmalarına konu olan bir problemdir. Mütekaddimîn kelâmcıları, genellikle fizik anlayışlarıyla daha uyumlu olan cismânî nefis anlayışını savunmuş ve bu konudaki görüşlerini eserlerinde açık bir şekilde ifade etmişlerdir. Ancak müteahhirîn dönemi kelâmc1larının insanî nefsin ${ }^{1}$ hakikati konusundaki görüşlerini, sadece nefsin tartışıldığı bölümlerden hareketle tespit etmek oldukça zordur. Bu bölümlerde müteahhirîn kelâmclarının, nefsin soyutluğu ve cismânîliği konusundaki görüşleri inceleyip her iki tarafın delillerinin de zayıflığına hükmettikleri ve kesin bir hüküm vermekten kaçındıkları görülür. Zira Allah dışındaki soyut varlıkları kesin olarak inkâr eden çoğu mütekaddimîn kelâmcısının aksine müteahhirîn dönemi kelâmcıları soyut cevherlerin reddinin dayandığı delillerin zayıf olduğunu söyleyerek bunların varlığını mümkün görmüşlerdir. Dolayısıyla onlara göre, bu görüşlerden birine kesin olarak hükmedip onu zorunlu, diğerini ise imkânsız görme şeklindeki bir yaklaşımın aklî olarak temellendirilmesi mümkün değildir. Her ne kadar bu düşünürler bir tarafa kesin olarak hükmetmenin mümkün olmadığını düşünseler de bu görüşlerden ikisinin bir düşünürün düşünce sistemiyle tutarlı olması beklenemez. Dolayısıyla bu düşünürlerin insanî nefis konusundaki görüşlerini netleştirmek için onların düşünce sistemlerindeki uzantılarının takip edilmesi ve ilişkili konulardaki görüşleriyle bir bütün halinde değerlendirmeye tabi tutulması gerekmektedir.

Müteahhirîn döneminin önde gelen kelâmcılarından Sa'düddin Teftâzânî (ö. 792/1390), insanî nefsin varlığı ve mahiyetini ayrıntılı bir şekilde tartı̧̧maktadır. Nefsin hakikatini ele aldığı bölümde cismânî nefis anlayışını benimsediğini gösteren bazı ifadelere yer verirken, diğer bazı açıklamaları ise soyut nefis görüşünü benimsediği yönünde anlaşılmaya elverişlidir. Dolayısıyla Teftâzânînnin konuyla ilgili görüşünü doğru bir şekilde tespit edebilmek için konunun düşünce sistemindeki

1 İslâm filozofları ve kelâmcılar, insanın hakikatini ifade etmek için genelde nefis ve ruh terimlerini kullanmışlardır. Ebû Hâmid Muhammed el-Gazzâlî, Me âricüll-kuds fî medârici márifeti’n-nefs (Beyrut: Dâru'l-Âfâki'l-Cedîde, 1975), 15-8; Ebû Hâmid Muhammed el-Gazzâlî, İhyâu ulûmi'd-dîn (Beyrut: Dâru'l-Marife, 2004), V, 13-9; Ebû Abdullah Şemseddin Muhammed İbn Kayyim el-Cevziyye, Kitâbu'r-Rûh, thk. Muhammed Ecmel Eyyûb el-Islâhî (Mekke: Dâru'l-Âlemi’l-Fevâid, 1432), II, 517-8; Ömer Türker, "Nefis: İslâm Düşüncesi”, DİA, XXXII, 529; Bk. Murtaza Korlaelçi, “Gazzâlînin İnsan Anlayışı”, 900. Vefat Yılında İmam Gazzâlî: Milletlerarası Tartışmalı İlmî Toplantı (İstanbul: Marmara Üniversitesi İlahiyat Fakültesi Vakfı Yayınları, 2012), 765; Mustafa Akçay, “Gazzâli'de Ruh Tasavvuru”, Dini Araştırmalar VII/21 (2005): 101-5; Ali Durusoy, İbn Sînâ Felsefesinde İnsan ve Alemdeki Yeri : Nefs, Ak1l ve Ruh (İstanbul: Marmara Üniversitesi İlahiyat Fakültesi Vakfı Yayınları, 2012), 34-9. Teftâzânî de "insanî nefis", "nefis" ve "ruh" gibi kavramları insanın hakikati anlamında kullanmaktadır. Sa‘düddin Mes'ûd b. Ömer b. Abdillah el-Herevî et-Teftâzânî, Şerhu'l-Makâsıd (İstanbul: Matbaa-i Muharrem Efendi, 1305), I, 235; II, 27-8, 30, 211-5, 217, 220-1. Bu çalışmada da insanî nefis, nefis ve ruh kavramları genel olarak "insanın hakikati" anlamında birbirlerinin yerine kullanılacaktır. 
izdüşümlerini takip etmek ve onlardan hareketle nefsin hakikatine dair görüşünü belirlemek daha doğru olacaktır. Bu çerçevede bu çalışmada öncelikle onun konuyla ilgili olarak tevarüs ettiği geleneği kendi yaklaşımına zemin hazırlayacak şekilde nasıl yorumladığı incelenecek, ardından da benimsediği görüş ana hatlarıyla zikredilecektir. Son olarak da bu görüşünün düşünce sistemindeki izdüşümlerinden hareketle nasıl ortaya çıkarıldığı açıklanacaktır.

\section{Nefsin Varlığı}

Araştırmaya konu olan bir mevcudun varlığına ve mahiyetine ilişkin tartışmaların birbirinden ayrıştırılması doğru sonuçlara ulaşılması açısından önem arz etmektedir. İslâm düşüncesinde nefsin varlığılla ilgili incelemenin esasında insanın, görülen ve duyumsanan bedenden mi ibaret olduğu, yoksa bu bedenin ötesinde bir şey (latif cisim veya soyut cevher) mi olduğu veyahut da bu ikisinin bütünü mü olduğu soruları üzerinden cereyan ettiği söylenebilir. İnsanın bu görülen bedenden ibaret kabul edilmesi aslında insanî nefsin bedenle özdeşleştirilmesi veya bedene indirgenmesi anlamına gelmektir. Bu tür bir yaklaşım, insanî nefsin varlığını inkâr anlamına gelmektedir. Ancak duyumsanan bedenin ötesinde veya ona içkin başka bir hakikatin insanda bulunduğu savunulduğunda nefsin varlığı da gerçek anlamda kabul edilmiş olunmaktadır.

Fahreddin Râzî (ö. 606/1210) "ben” sözüyle işaret edilen bir şeyin bulunmasının apaçık (bedîhî) olduğunu söyler. "Ben" diye işaret edilen şeyin; bu beden, bedene içkin bir cisim, bedenle kaim bir araz, gayri cismânî bir cevher vb. olması ise bedîhî değil, delille sabit olmaktadır. Şu hâlde Râzîye göre "ben” diye işaret edilen şeyin varlığı bedîhî iken, onun bedenin ötesinde olup olmadığı apaçık bilgilerden değildir. ${ }^{2}$ Diğer bir ifadeyle Râzî, aslında nefsin varlığının inkârı edilmesi şeklinde anlaşılabilecek olan nefsin bedenle özdeşleştirilmesi görüşünün yanlışlığını gösterip bedenden farklı bir nefsin varlığının ispatı için delile ihtiyaç olduğunu düşünmektedir. Bu yaklaşım Şemsüddin Semerkandî (ö. 702/1303) tarafından da sürdürülmüştür. ${ }^{3}$

Mezkûr yaklaşımın aksine Teftâzânî, sadece "ben” diye işaret edilen bir öznenin varlığının değil, onun bedenin ötesinde olmasının da bedîhî olduğunu ve bunun zorunlu olarak bilindiğini söylemektedir. Teftâzânî ile Râzî ve Semerkandî gibi dü-

3 Şemsüddin es-Semerkandî, es-Sahâifü'l-ilâhiyye, thk. Ahmed Abdurrahman Şerif (Kuveyt: Mektebetü'l-Felâh, 1985), 272-4. 
şünürler arasındaki bu farklılaşma ileride değinileceği üzere onların nefsin hakikati konusunda tevarüs ettikleri geleneği farklı yorumlamalarıyla ilişkilidir. Teftâzânî̀ye göre, insanın sürekli olarak değişen, dağılıp parçalanan ve duyumsanan bedeninin (heykel-i mahsûs) ötesinde bir ruhu vardır. Bu bedenin ötesinde bir ruhun bulunduğuna kesin nasların şahitlik etmesinin yanı sıra böyle bir ruhun varlığı zorunlukla bilinmektedir. ${ }^{4}$ Kelâmcılar, nefsin varlığını açıklamak için naslara ve "aklî uyarılar"a (et-tenbîhâtü'l-'akliyye) dayanmıştır. ${ }^{5}$ Şu hâlde Teftâzânî̀ye göre, delillerden hareketle duyumsanan bedenden başka olan bir nefsin varlığını temellendirmeye gerek olmayıp sadece mesele üzerindeki ince perdenin kaldırılması sadedinde bazı aklî uyarılarla onun varlığına işarette bulunabilir ve naslarla da bu husus teyit edilir. Bedîhî veya zarurî olmakla birlikte kısmen kapalı gibi duran hükümlerin delillendirilmesi sadedinde zikredilen önermeler delil değil, sadece "uyarıcı olma" niteliğini taşır. ${ }^{6} \mathrm{Bu}$ çerçevede Teftâzânî, nefsin varlığını gösteren üç tane aklî uyarıyı zikreder: Birincisi, dış ve iç organlarıyla birlikte insan bedeni sürekli olarak değişmesine rağmen kişi olduğu gibi kalmaktadır. İkincisi, akıl sahibi olan insan bazen beden ve organlarından gâfil olabilirken kendi zâtının varlığından hiçbir zaman gâfil kalmaz. Üçüncüsü ise insan, bedeni kendisini engellemesine rağmen yukarıya doğru yükselme gibi yapısına aykırı şeyleri ister. ${ }^{7}$ Eğer insan bu bedenden ibaret olsaydı bedenin yapısına uygun olmayan bu tür şeyler onun tarafından arzu edilmezdi.

Teftâzânî̀ye göre, insanî nefsin varlığını kabul eden filozoflar, onun varlığını türsel suret görüşlerinden hareketle temellendirmişlerdir. Fasıl cinse eklenerek türü meydana getirdiği gibi dışta da nefis bedene taalluk etmek suretiyle insan türünün meydana gelmesini sağlar. İnsanın meydana gelmesi için onun türsel suretinin maddeye taalluk etmesi gerekmektedir. İnsan türü cisimlik itibariyle diğer türlerle aynı

Sa‘düddin Mes'ud b. Ömer b. Abdillah el-Herevî et-Teftâzânî, "Makâsıd”, Şerhu'l-Makâsıd (İstanbul: Matbaa-i Muharrem Efendi, 1305), II, 29; Ziya Erdinç, “Teftâzânîde Bilen Bir Özne Olarak İnsan”, İnsan Nedir? İslâm Düşüncesinde İnsan Tasavvurları, ed. Ömer Türker ve İbrahim Halil Üçer (Ankara: İLEM Yayınlar1, 2019), 245-8.

5 Teftâzânî, Şerhu'l-Makâsıd, II, 29.

6 Teftâzânî, Şerhu'l-Makâsıd, I, 60, 140.

7 Teftâzânî, Şerhu'l-Makâsıd, II, 29. Bu delillerin bir kısmı İbn Sînâ tarafından nefsin soyut bir cevher olduğunu temellendirmek için kullanılırken Râzî ve Semerkandî gibi kelâmcılar ise onları nefsin bedenden ibaret olmadığının delilleri olarak zikretmiştir. Bk. İbn Sînâ, Kitâbu'ş-Şifâ: Kitâbu'n-Nefs, ed. Fazlurrahman (Londra: University of Durham, 1959), 252-7; Fahreddin er-Râzî, el-Erba'în fì usûli'd-dîn, thk. Ahmed Hicâzî es-Sekâ (Kahire: Mektebetü'l-Külliyâti'l-Ezheriyye, 1986), II, 18-24; Semerkandî, es-Sahâifü'l-ilâhiyye, 272. Teftâzânî'nin bu delilleri kullanma biçimi ise bu düşünürlerden farklıdır. Zira hem burada hem de ilerleyen sayfalarda detaylı bir şekilde incelendiği üzere Teftâzânî, nefsin duyulur bedenin ötesinde olmasının bedahetine inandığından zikredilen argümanları delil değil, aklî tenbihler olarak kabul etmekte ve nefsin bedenin ötesinde bulunmasını filozofların soyut cevher görüşüne münhasır görmemektedir. Yani bedenin ötesinde bulunan nefsin soyut olması aklen mümkün olduğu gibi cismânî olması da mümkündür. 
olmasına rağmen, onu diğerlerinden farklı kılan cisimlikten uzak bir ilkenin olması zorunludur. Yine insan bedeninden çok farklı fiillerin meydana geldiği görülmektedir. Bu fiillerin kaynağı olacak bir ilkenin bulunması gerekir. İște onlara göre, bu ilke ve türsel suret nefistir. ${ }^{8}$ Ancak kelâmcılar ise filozofların aksine nefsi türleştirici bir fasıl olarak görmediklerinden ve bedenden ortaya çıan fiillerin tamamını Allah'a dayandırdıklarından nefsin varlığını naslar ve aklî uyarılarla açıklamışlardır. ${ }^{9}$ Öyle görünüyor ki Teftâzânî, kendisinin de benimsediği nefsin varlığının bedîhî olduğu görüşünün aslında kelâmcıların geneli tarafından savunulduğunu düşünmektedir.

\section{2. İnsanî Nefsin Hakikati Konusundaki Anlayışlar}

İslâm düşünürleri çok erken dönemlerden itibaren insanın hakikatinin ne olduğunu tartışmışlardır. Düşünürler, kendi düşünce sistemleri doğrultusunda insanî nefsin hakikatine ilişkin farklı yaklaşımlar ileri sürmüşlerdir. Tevarüs edilen yaklaşımların nasıl anlaşılacağı ve yorumlanacağı konusunda da zaman zaman farklılıklar meydana gelmiştir. Görüşleri araştırılan düşünürün tevarüs ettiği geleneği nasıl yorumladığı ve yorumlamasındaki farklılıklar onun düşüncesinin arka planını anlamak açısından önem taşımaktadır.

Müteahhir dönemde Teftâzânî öncesinde insanî nefsin hakikatine dair yaklaşımları en detaylı şekilde taksim edip hangi görüşün kimler tarafından ileri sürüldüğünü inceleyen düşünürün Râzî olduğu görülmektedir. Râzîdden sonra bu yaklaşımları detaylı bir şekilde inceleyen diğer bir önemli bir düşünür olan Şemsüddin Semerkandînnin görüşlere dair taksimi ise neredeyse onunkiyle aynıdır. ${ }^{10} \mathrm{Bu}$ yüzden Teftâzânînin görüşleri nasıl taksim ettiğine geçilmeden önce Râzînnin yaklaşımı incelenecektir.

İnsanın hakikatine dair görüşlerin aklî bir taksimini yapan Râzî, varlığı zorunlu olarak bilinen ve "ben" diye işaret edilen öznenin hakikati konusunda üç ihtimalin bulunduğunu söyler: (i) cisim, (ii) cisme sirayet etmiş bir araz ve (iii) cisim ve cisme sirayet etmiş arazdan başka bir varlık. Birinci kısım (i) ise üçe ayrılır: (i.i) bedenin kendisi, (i.ii) bedene içkin olan başka bir cisim ve (i.iii) bedenin tamamen dışında olan bir cisim. Bedene içkin başka bir cisim olduğunu söyleyenler (i.ii) de bu cismin ne olduğu konusunda farklı görüşler ileri sürmüşlerdir: (i.ii.i) ahlât-1 erbaa, (i.ii.ii) kan, (i.ii.iii) latif kan, (i.ii.iv) kalpten beyne çıkan ruh, (i.ii.v) atom, (i.ii.vi) mahiyet bakımından diğer cisimlerden farklı, nurânî ve zâtı gereği hay olan cisim, (i.ii.vii)

10 Semerkandî, es-Sahâifü'l-ilâhiyye, 272-82. 
ömrün başından sonuna kadar devam eden aslî parçalar ve (i.ii.viii) onlar olmaksızın hayatın bulunmadığ1 temel organlar. ${ }^{11}$ Râzî̀ye göre, bu taksimde nefsin araz olduğu yönündeki (ii) numaralı görüş akıllı bir kimsenin savunacağı bir fikir değildir. Diğer taraftan insanın hakikatinin cisim olması ihtimali (i) altında yer alan (i.iii) numaralı görüş, ona göre, hiç kimse tarafından ileri sürülmemiş olup sadece aklî bir ihtimal olarak zikredilmiştir. ${ }^{12}$

Bedenin ötesindeki bir nefsin varlığının naslarla ve aklî uyarılarla sabit olduğunu düşünen Teftâzânî, nefsin hakikatinin ne olduğu konusunda ekollerin görüşlerinin farklılaştığını belirtir. Ona göre, bedenin ötesindeki bir nefsin varlığı bedîhî olmasına rağmen hakikatinin gayri maddî bir cevher mi yoksa cisim mi olduğu hususunda ayetlerin delâletlerinde herhangi bir kesinlik bulunmamaktadır. Ayetlerin delâlet ettiği şey, sadece insanın hakikatinin bu değişip dönüşen bedenden başka bir varlık olduğudur. ${ }^{13}$ Dolayısıyla naslar açısından bakıldığında bedenin ötesindeki hakikat, soyut bir cevher olabileceği gibi cismânî bir özne de olabilir.

Teftâzânî’ye göre nefsin hakikatinin ne olduğuna ilişkin şu görüşler ileri sürülmüştür: (i) Duyulur bedendeki ateş, (ii) hava, (iii) su, (iv) dört unsur (manevî), (v) ahlât-1 erbaa, (vi) özel mizaç, (vii) kalpteki atom, (viii) aslî parçalar, (ix) mahiyet bakımından diğer cisimlerden farklı latif cisim, (x) kalpte oluşan latif cisim ve (xi) soyut nefis. Nefsin hakikatine ilişkin bu görüşleri aktardıktan sonra o, bu görüşlerden her birine dayanak oluşturan argümanları incelemek yerine "nefsin cisimsel olduğunu savunanlar" ile "nefsin soyut bir cevher olduğunu savunanlar" 1 argümanlarını tartışır. ${ }^{14}$ Böylece Teftâzânî, cisimsel yapıda bir nefis tasavvuruna sahip ilk on görüşü "cismânî nefis" kapsamında değerlendirdiğini göstermektedir. $O$, sonuncu sirada yer verilen soyut nefis görüşünü ise "zâtında soyut olmakla birlikte bedenle tedbir ve tasarruf ilişkisi içinde bulunan nefis" şeklinde ifade etmektedir. ${ }^{15}$ Açı kça görülmektedir ki o, filozoflara ve bazı kelâmcılara nispet ettiği soyut nefis görüşüyle "maddî süreçlerle doğrudan bir ilişki içinde bulunmamak" anlamında bir soyutluğu değil, "nefsin, zâtında gayri maddî bir yapıda kabul edilmesi" manasındaki soyutluğu kastetmektedir.

Râzînin sadece aklî bir ihtimal olarak zikrettiği görüş (i.iii) ile akıllı kimseler tarafından savunulmadığını söylediği görüş (ii) Teftâzânî̀nin taksiminde yer almamaktadır. Zira Râzî̀nin aksine o, aklî bir taksim yapmaktan ziyade konuyla ilgili 
mevcut görüşleri sıralamaya çalışır. Yine nefsin bedenin ötesinde bulunmasını bedîhî kabul eden Teftâzânî, Râzînnin taksiminde yer alan nefsin bedene özdeş olması (i.i) görüşüne de yer vermemektedir.

Görüldüğü gibi Teftâzânî, nefsin bedenin ötesinde olduğunu açıkladıktan sonra bu kapsamda yer aldığını düşündüğü cismânî nefis ve soyut nefis görüşlerini zikretmektedir. Bedenden tamamen farklı bir varlık tarzına sahip soyut nefsin bedenin ötesinde olduğu açıktır. Ancak bedenle aynı varlık tarzına sahip bir cismin bedenin ötesinde olması nasıl anlaşılmalıdır? Aşağıda nefisle ilgili görüşler incelenirken görüleceği üzere Teftâzânî, duyularla idrak edilen ve duyumsanan şeyin beden olduğunu, ancak cismânî kabul edilen insanî nefsin duyumsanmadığını, yani duyu organlarıyla idrak edilmediğini düşünmektedir. Buna göre eğer nefsin cismânîliği savunuluyorsa onun bedenin ötesinde olmasıyla kastedilen şey, bedene içkin olması ve duyu organlarıyla idrak edilmemesidir. Zira duyu güçleriyle idrak edilen bedenin tüm parçaları değişmesine rağmen nefsin aynı kaldığı bilinmektedir.

\subsection{Cismânî Nefis Görüşü}

İnsanî nefsin cisimsel bir yapıda olduğunu savunanlar bu cismânî öznenin ne olduğu konusunda birbirinden farklı görüşler ileri sürmüşlerdir. Nitekim Râzî ve Teftâzânînin yer verdiği taksimlerde de değinildiği üzere bu görüşlerin sayısı onu bulmaktadır.

Bu çalışmada nefsi cismânî kabul edenlerin tamamının görüşlerini incelemek çalışmanın sınırlarını aşacaktır. Bu yüzden gerek kaynaklarda öne çıkmaları ve kelâmcılara nispet edilmesi, gerekse de Teftâzânînin daha fazla üzerinde durması sebebiyle bu çalışma açısından son derece önemli olan üç görüş üzerinde durulacaktır: bünye/yap1, aslî parçalar ve latif cisim.

\subsubsection{Bünye/Yapı}

Cismânî nefis anlayışı kapsamında zikredilmesi gereken en önemli görüşlerden biri özel yapı (el-heykelü'l-mahsûs) veya duyumsa(y/n)an bünye (el-bünyetü'l-mahsûs) şeklinde ifade edilen görüştür. Genellikle kelâmcılara nisbet edilen bu görüşün nasıl anlaşılması ve yorumlanması gerektiği müteahhirîn düşünürleri arasında farklılık göstermektedir. Bazı düşünürler onunla bu görülen ve duyumsanan bedenin kastedildiğini savunurken, diğerleri ise bu bedene içkin olarak bulunan duyumsayan bir öznenin murat edildiğini ileri sürmüşlerdir.

Erbaîn ve Metâlib'deki taksiminde Râzî, nefsin hakikatinin cisim olduğuna ilişkin görüşler arasında yer verdiği “(i.i) nefsin bedene özdeş olması” görüşünü kelâmc1ların çoğunluğuna nispet eder. Bu görüşü açıklamak için o, aynı zamanda özel yapı 
(el-heykelü'l-mahṣ̣̂s) kavramını kullanır. ${ }^{16}$ Muhassal adlı eserinde de Râzî kelâmcların çoğunluğunun görüşünü "nefsin bu duyulur bünye (el-bünyetü'l-mahsûs) olması" şeklinde zikreder. ${ }^{17}$ Dolayısıyla onun her iki kavramla kelâmcıların çoğunluğuna nispet ettiği görüş, nefsin bedene özdeş olmasıdır. Eğer onun açıklamaları doğru ise kelâmcıların çoğunluğunun bedenin ötesinde bir ruhun varlığını inkâr ettikleri ve insanı bedenden ibaret gören katı monist bir görüşü benimsediklerini söylemek gerekecektir. Nitekim bu görüşün zayıflı̆̆ına ilişkin olarak getirdiği deliller, Râzînin özel yapı ve bünyeyle görülen ve duyumsanan bu bedeni kastettiğini göstermektedir. ${ }^{18}$ Şemsüddin Semerkandî de Râzî gibi yapı veya bünye görüşünü nefsin bedene özdeş k1lınması şeklinde yorumlayarak bu görüşü kelâmcıların çoğunluğuna nispet eder. Yine o, bu görüşün zayıf olduğunu gösteren deliller konusunda da Râzî̀yi takip eder. ${ }^{19}$

Mütekaddimîn dönem literatüründe Râzînin yorumunun dayanaklarını bulmak mümkündür. Örneğin Mu'tezilî kaynaklar mütekaddimîn döneme ait önde gelen kelâm ve fırak metinlerinde "insanın duyumsanan bedenden ibaret görülmesi" görüşünün Mu'tezilî düşünürlere nispet edildiği görülmektedir. Kaynakların verdiği bilgilere göre Ebü'l-Hüzeyl el-Allâf (ö. 235/849), Ebû Ali el-Cübbâî (ö. 303/916), Ebû Hâşim el-Cübbâ̂̂ (ö. 321/933) ve Kâdî Abdülcebbâr (ö. 415/1025) gibi Mu'tezilî düşünürlere insanı bu bedenden ibaret kabul etmişlerdir. ${ }^{20}$ Kâdî Abdülcebbâr'ın açılamaları

Râzî, Metâlib, VII, 35; Râzî, el-Erba în, II, 18.

Ebû Abdullah Fahreddin Muhammed b. Ömer Fahreddin er-Râzî, Muhassalu efkâri'l-mütekaddimîn ve'l-müteahhirîn mine'l-ulema, nşr. Taha Abdürrauf Sa'd (Kahire, t.y.), 223.

Râzî, el-Erba'în, II, 18-24; Râzî, Muhassal, 223-4.

Semerkandî, es-Sahâifü'l-ilâhiyye, 272; Şemsüddin Semerkandî, İlmü'l-âfâk ve'l-enfüs: Âlem ve İnsan, thk. Yusuf Okşar ve İsmail Yürük (İstanbul: Türkiye Yazma Eserler Kurumu Başkanlığı Yayınları, 2020), 37980; Ramazan Biçer, "Şemseddin Semerkandîye Göre İnsan Psikolojisinin Temel Nitelikleri”, Al Farabi IV. Uluslararası Sosyal Bilimler Kongresi Kongre Tam Metin Kitabı, ed. Özlem Ülger ve Atabek Movlyanov (İksad Yaynevi, 2019), 856; Krş. Râzî, el-Erbaî̀n, II, 18-24.

Ebü'l-Kâsım el-Ka'bî el-Belhî, Kitâbu'l-Makâlât ve meahû Uyûnu'l-mesâil ve'l-cevâbât, thk. Hüseyin Hansu, Râcih Kürdî, Abdülhamîd Kürdî (İstanbul-Amman: Kuramer-Dâru'l-Feth, 2018), 461; Ebü'l-Hasan elEş'arî, Makâlâtü'l-İslâmiyyîn: İlk Dönem İslâm Mezhepleri, haz. Ömer Aydın ve Mehmet Dalkılıç (İstanbul: Türkiye Yazma Eserler Kurumu Başkanlığı Yayınları, 2019), 463; Yunus Cengiz, "Mu'tezile'nin İnsan Düşüncesinde Rakip İki Tasavvur: Ebü'l-Hüzeyl ve Nazzâm Gelenekleri”, Nazariyat İslâm Felsefe ve Bilim Tarihi Araştırmaları Dergisi 4/2 (Nisan 2018): 57, 63. Kâdî Abdülcebbâr’a göre insan, onu diğer varlıklardan ayıran özel bünyesi sayesinde bu şahıstır. Bu özel bünyesi bulunan ve hayata sahip olan şeye, insan denilir. Bu anlamda heykel de insana ait özel bünyeye sahip olsa bile canlı olmadığı için insan olarak nitelendirilemez. İnsan, bedeni oluşturan bütün parçalarıyla birlikte kendisidir. Bedenin parçalarıyla kastedilen bütüne bitişik ve canlı olan parçalardır. Buna göre kan, saç, tırnak ve salya gibi parçalar canlı olmadıklarından insan bedeninin parçası değildirler. Dolayısıyla insanın bir parçası da olamazlar. Benzer şekilde çoğu canlı olmayan kemikler de bedeninin parçası değildir. Ebü'l-Hasen Kâdî Abdülcebbâr, el-Mugnî fi ebvâbi't-tevhîd ve'l-adl: et-teklîf, nşr. Muhammed Ali en-Neccâr ve Abdülhalîm en-Neccâr (Kahire: ed-Dâru'l-Misriyye, 1965), XI, 311-12, 331; Margaretha T. Heemskerk, "'Abd al-Jabbār al-Hamadhānī on Body, Soul and Resurrection”, A Common Rationality: Mu'tazilism in Islam and Judaism, ed. Camilla Adang, Sabine Schmidtke, ve David Sklare (Würzburg: Ergon Verlag in Kommission, 2007), 127-34; Cengiz, “Mu‘tezile'nin İnsan Düşüncesinde Rakip İki Tasavvur”, 63-5. 
incelendiğinde onun insanı, özel bünyeye ve hayata sahip bir şahıs olarak gördüğü anlaşılmaktadır. Bu durumda onun, nefsi duyulur bedenle özdeşleştirdiği ve bedenin ötesinde bir ruhun varlığını kabul etmediği görülmektedir. Her ne kadar nefes ve rüzgâr kabilinden bir ruhun varlığını kabul etse de ona göre, hayatın kendisinde bulunmadığı bu ruh, insanın hakikatinin ne kendisi ne de bir parçasıdır. ${ }^{21}$

Bazı kelâmcılar ise Râzînnin aksine bünyeyle duyumsanan bedenin değil, ona içkin olarak bulunan aslî parçaların (el-eczâu'l-așliyye) kastedildiğini düşünmüşlerdir. Bu bağlamda insanın hakikatinin belirli yapıdaki bünye olduğunu savunan Mu'tezilî âlim İbnü'l-Melâhimî (ö. 536/1141), bu görüşe yönelik eleştirilere verdiği cevapta, insanı insan yapan özün aslî parçalar olduğunu ifade eder. Ona göre, bir insanın hayatı boyunca sürekli değişen parçaları onun fazlalık parçaları iken değişmeden kalan ve onu kendisi kılan parçalar ise aslî parçalardır.22 Diğer bir Mu'tezilî bilgin Takıyyüddin en-Necrânî (ö. VII./XIII. yüzyıl) de yukarıda bünye görüşünü savundukları ifade edilen Ebû Ali el-Cübbâî, Ebû Hâşim ve Kâdî Abdülcebbâr'a aslî parçalar görüşünü nispet etmektedir. Bu da onun bünyeyi aslî parçalar şeklinde yorumladığını göstermektedir. ${ }^{23}$ Kelâmcıların bünyeyle aslî parçaları kastettiğini savunan diğer bir düşünür de Nasîrüddin Tûsîdir (ö. 672/1274). ${ }^{24}$ O, Râzînin bünyenin sıfatı olan “mahsûs" kelimesini renk ve şekil gibi duyumsanan varlıklar anlamında açıklamasını hatalı bulur. Ona göre kelâmcılar, "mahsûs" kaydıyla bünyenin ve aslî parçaların duyumsanması, yani duyularla idrak edilmesini kastetmemişlerdir. Aksine buradaki "mahsûs" kaydıyla bünye sayesinde duyumsamanın gerçekleştiği ifade edilmek istenmiştir. ${ }^{25}$ Şu hâlde el-bünyetü'l-mahsûs tamlaması, Râzî tarafından "duyumsanan bünye” şeklinde anlaşılırken Tûsî ise onu "duyumsayan bünye" şeklinde yorumlamaktadır.

İnsanî nefsin bedenin ötesinde olmasını bedîhî kabul etmesinden dolayı Teftâzânî, kelâmcıların çoğunluğuna nispet edilen bünye görüşünü Râzî gibi "nefsin bedene özdeş olması" şeklinde yorumlaması halinde şu soruyla karşı karşıya kalacaktır: Nefsin bedenin ötesinde olduğu bedîhî ise kelâmcıların çoğunluğu bedîhîye aykırı olan bir görüşü nasil benimseyebilmişler? Râzî, "ben” diye işaret olunan öznenin bedene içkin Wilfred Madelung (Tahran: Iranian Institute of Philosophy-Institute of Islamic Studies Free University of Berlin, 2008), 155, 166-7, 175-6; Rüknüddin İbnü'l-Melâhimî el-Hârizmî, Kitâbu'l-Fâikfî usûli'd-dîn, thk. Wilfred Madelung ve Martin McDermott (Tahran: Iranian Institute of Philosophy-Institute of Islamic Studies Free University of Berlin, 2007), 225-6.

23 Takıyyüddîn Muhtâr b. Mahmûd Necrânî, el-Kâmil fi'l-istiksâ fí mâ beleganâ min kelâmi'l-kudemâ, thk. es-Seyyid Muhammed eş-Şâhid (Kahire: el-Meclisü'l-A'lâ li'ş-Şuûni'l-İslâmiyye, 1999), 427, 431.

24 Ebû Ca'fer Nasîrüddîn Muhammed b. Muhammed Tûsî, Telhîsü'l-Muhassal (Beyrut: Dârü'l-Edvâ', 1985), 379.

25 Tûsî, Telhîs, 379. 
(Teftâzânînin ifadesiyle bedenin ötesinde) olmasını değil, hangi mahiyette kabul edilirse edilsin varlığını bedîhî gördüğünden bu soruya muhatap olmamaktadır. İşte Teftâzânî, el-bünyetü'l-mahsûs ile ilgili olarak Tûsînnin yorumunu doğru kabul edip mezkûr soruya muhatap olmamıştır. Bu çerçevede Teftâzânî, el-bünyetü'l-mahsûs ifadesini duyumsayan bünye şeklinde açıklar; bünye ve yapı ile kastedilen şeyin aslî parçalar olduğunu ve bu görüşün kelâmcıların çoğunluğu tarafından savunulduğunu belirtir. ${ }^{26}$ Böylece o, kelâmcıların çoğunluğunun bedîhîye aykırı olan "nefsin bedene özdeş olması” görüşünü savunduklarını söylemek durumunda kalmamıştır.

\subsubsection{Aslî Parçalar}

Nefsin hakikatine ilişkin önemli görüşlerden birisi de onun aslî parçalardan ibaret olduğudur. Râzînnin taksiminde aslî parçalar, nefsin bedene içkin olması ihtimali altında yer alan görüşlerden biridir. İnsanın aslî parçalarıyla kastedilen, ömrün başından sonuna kadar devam eden parçalardır. ${ }^{27}$ Muhakkiklerin tercih ettiği görüşün aslî parçalar olduğunu ifade eden Râzî, bu görüş sayesinde haşri reddedenlerin şüphelerinin birçoğunun savuşturulabileceğini söyler. ${ }^{28}$

Teftâzânî’ye göre birçok kelâmcı tarafından benimsenen aslî parçalar görüşü, yukarıda da açıklandığı üzere bünye ve yapı görüşüyle aynıdır. Diğer bir ifadeyle ona göre bünye görüşünü savunanların bünyeyle kastettikleri şey beden değil, bedene karışmış olarak bulunan aslî parçalardır. Aslî parçalar, ömrün başından sonuna kadar insanda mevcut bulunan parçalardır. ${ }^{29}$

\subsubsection{Latif Cisim}

İnsanî nefsin latif cisim olduğu konusundaki görüşler, aralarındaki farklılıklar dolayısıyla üç kısımda incelenecektir: (i) kalpte veya beyinde oluşan latif cisim; (ii) diğer cisimlerden farklı hakikate sahip latif cisim ve (iii) diğer cisimlerle aynı hakikate sahip latif cisim.

Kalpte veya beyinde oluşan latif cisim: Gerek Râzînin (i.ii.iv numaralı görüş) gerek Teftâzânînin taksiminde (x numaralı) yer alan görüşlerden birisi de nefsin

28 Râzî, el-Erbaî̂n, II, 27, 61; Eşref Altaş, "Fahreddîn er-Râzîye Göre İnsanın Mahiyeti ve Hakikati -Mücerred Nefs Görüşünün Eleştirisi-”, İnsan Nedir?: İslâm Düşüncesinde İnsan Tasavvurları (Ankara: İLEM Yayınları, 2019), 157. Aslî parçalar görüşünün ahiret inancıyla ilgili bazı sorulara cevap sağlamasındaki önemi için bk. İbnü'l-Melâhimî, Tuhfetü'l-mütekellimîn, 185-6; Necrânî, el-Kâmil, 425, 427. 
kalpte veya beyinde oluşan latif cisim olmasıdır. Bu görüşü benimseyenlere göre, insanî nefis, kalpte oluşup damarlar yoluyla organlara sirayet eden veyahut da beyinde oluşup onda bulunan sinirlere nüfuz eden ve oradan da tüm bedene yayılan latif cisimdir. Nefsin oluştuğu yerin kalp veya beyin olarak kabul edilmesine bağlı olarak bu görüşün iki kısma ayrıldığı görülmektedir. ${ }^{30}$ Teftâzânî̀ye göre kalpte veya beyinde oluşan latif cisim, kelâmcıların bazen "hayvanî ruh" bazen de "kalbî ruh" şeklinde isimlendirdiği ruhtur. ${ }^{31}$ Diğer bir ifadeyle ona göre, her ne kadar bazıları tarafından insanî nefsin hakikati olarak kabul edilse de kelâmcılar bunu insanî nefis değil, hayvanî ruh olarak kabul etmişlerdir.

Diğer cisimlerden farklı hakikate sahip latif cisim: Kelâmcılara nispet edilen latif cisimle genelde bu görüş kastedilmektedir. Râzîye göre, nefsin bedene karışmış cisim olması ihtimali altında yer alan görüşlerden birisi de onun gül suyunun güle, ateşin kömüre ve yağın susama sirayet etmesi gibi bedene karıştığı nurânî, ulvî, hafif ve zâtı gereği canlı olan latif bir cisim olmasıdır. İnsanın bedeni ömür boyunca değişmesine ve vefattan sonra dağılıp parçalanmasına rağmen insanî nefis, diğer cisimlerden farklı bir mahiyete sahip olduğundan dolayı değişmeden ve parçalanıp dağılmadan kalabilmektedir. ${ }^{32}$ Nazzâm (ö. 231/845) ve Câhız (ö. 255/868) gibi Mu'tezilî âlimlere nisbet edilen latif cisim görüşünün bu doğrultuda açıklandiğı görülmektedir. ${ }^{33}$ Teftâzânî̀ye göre kelâmcıların cumhuru bu görüşü savunmuştur. ${ }^{34}$

Diğer cisimlerle aynı hakikate sahip latif cisim: Nefsin diğer cisimlerle farklı hakikate sahip latif cisim olduğu görüşünün dayandığı belirli bir fizik anlayışı vardır. Bu fizik anlayışında cisimlerin farklı hakikatlere sahip olduğunu kabul etmek gerekir. Ancak bu görüş, cisimlerin aynı hakikate sahip (mütemâsil/benzeşik) olduğunu savunanların fizik anlayışına uygun değildir. Bu çerçevede latif cisim kapsamında zikredilmesi gereken diğer bir görüş de insan nefsinin diğer cisimlerle aynı hakikate sahip bir latif cisim olduğudur. Zira insanın ömrünün başından sonuna kadar değişmeden kalması ve ölümden sonra bedeni dağılmasına rağmen kendisinin hayatta kalmaya devam etmesi için nefsin diğer cisimlerden farklı hakikate sahip olması gerekmez. Aksine Fâil-i Muhtar olan Allah, insanî nefiste -her ne kadar diğer cisimlerle aynı hakikate sahip olsa bile-ictimâ (birleşme), hayât ve bekâ gibi arazları yaratmak suretiyle onu bedenden farklı kılabilir. Bu durumda insanî 
nefsin diğer cisimlerden farklılığı hakikat bakımından değil, arazlar yönünden gerçekleşmektedir.

Şerhu'l-Makâsıd'da insanî nefsin hakikatine ilişkin aktardığg görüşler arasında ilk iki latif cisim görüşüne yer veren Teftâzânî bu üçüncü görüşe dair bir bilgi vermez. Muhtasar olarak yazılmış Makâsıd metninde ve Tehzîbu'l-mantık ve kelâm eserinde ise o, farklı görüşlerin tamamını zikretmeden sadece itimat edilen üç tane görüşe yer verir. Ona göre, bunlardan aslî parçalar ve latif cisim görüşleri kelâmcılar tarafından savunulurken, soyut nefis görüşü ise bazı kelâmcılar ve filozoflara aittir. Burada Teftâzânî, Şerhu'l-Makâsıd'daki ifadelerinin aksine latif cisim görüşünü zikrederken "diğer cisimlerden farklı olan" kaydına yer vermez. Böylece o latif cisim görüşünü, hem hakikat bakımından diğer cisimlerden farklı latif cisim hem de hakikat bakımından diğer cisimlerle aynı olan latif cisim görüşünü içerecek şekilde kullanır. ${ }^{35}$ Nitekim o, insanî nefislerin cisim, cisimlerin de benzeşik olduğunu savunanların insanî nefislerin hayvanî nefislerle benzeşik olduğunu kabul etmeleri ve aralarındaki farklıkları da onların hakikatlerine değil, arazlara dayandırmaları gerektiğini ifade eder. ${ }^{36}$

Sonuç olarak Teftâzânîn nin konuyla ilgili olarak farklı bölümlerde aktardığı bilgiler dikkate alındığında onun, insanî nefsin hakikatinin latif cisim olduğunu söyleyen kelâmcıların görüşlerini "farklı hakikate sahip latif cisim" ve "aynı hakikate sahip latif cisim” olmak iki kısma ayırdığı söylenebilir.

\subsection{Soyut Cevher Görüşü}

Tabiatçı filozofların insan nefsini bedenin kendisi, mizaç, kan ve ahlât-1 erbaa vb. cismânî şeyler olarak gördükleri ifade edilmekle birlikte özellikle İslâm felsefî gelenekleri söz konusu olduğunda hâkim insanî nefis anlayışının soyut cevher görüşü olduğu söylenebilir. Varlıklara dair taksimlerini soyut cevherleri de içine alacak şekilde ortaya koyan İslâm filozofların çoğunluğu, insanî nefsin soyut bir cevher olduğunu düşünmektedir. ${ }^{37}$

Teftâzânî, “Makâsıd”, II, 29; Sa'düddin Mes'ud b. Ömer b. Abdillah el-Herevî Teftâzânî, Tehzîbu'l-mantık ve'l-kelâm, nşr. Abdülkadir Kürdî (Kahire: Matbaatü's-Saade, 1912), 71. Meâd bahsinde ise Teftâzânî, insanın hakikatini ifade ederken "latif" kaydı olmaksızın zikrettiği cismi, "farklı hakikate sahip latif cisim” ve "aynı hakikate sahip latif cisim" görüşlerinin yanı sıra "aslî parçalar görüşü” nü de ihtiva edecek şekilde en geniş haliyle kullanır. Teftâzânî, Şerhu'l-Makâsıd, II, 211.

36 Teftâzânî, Şerhu'l-Makâsıd, II, 35.

37 İbn Sînâ, Metafizik, çev. Ekrem Demirli ve Ömer Türker, 2. bs. (İstanbul: Litera Yayıncılık, 2013), I, 56; Şihâbüddîn Sühreverdî, "Hikmetü'l-işrâk”, Mecmû'a-ı Musannefât-ı Şeyh-i İşrâk, nşr. Henri Corbin (Tahran: Pejûheşgâh-1 Ulûm-1 İnsanî ve Motâleât-1 Ferhengî, 1993), II, 61-62. İslâm filozoflarının insanî nefse dair görüşleri, Aristoteles ve Platon'a dayanmaktadır. Fârâbî ve İbn Sînâ gibi filozoflar Aristoteles'in 
Râzî̀ye göre, metafizikçi filozofların çoğu, Nevbahtî (ö. 311/924), Şeyh Müfîd (ö. 413/1022), Muammer b. Abbâd (ö. 215/830), Gazzâlî ve muhakkik sûfîlerden bir grup, insanî nefsin ne mekanlı (mütehayyiz) ne de mekanliya yerleşen soyut bir cevher olduğunu savunmuşlardır. ${ }^{38}$ Teftâzânî de bu görüşü filozofların yanı sıra Ka'bî (ö. 319/931), Halîmî (ö. 403/1012), Râg1b el-İsfahânî (ö. 502/1108), Ebû Zeyd ed-Debûsî (ö. 430/1039), Gazzâlî, sûfîler, Şîa ve Kerrâmiyye’nin çoğunluğuna nispet etmektedir. ${ }^{39}$ Tehzîb'de ise bunu, filozoflar ile bazı kelâmcılar tarafından savunulan ve itimat edilen bir görüş olarak zikreder. ${ }^{40}$

Mütekaddimîn dönem kelâm düşüncesinde nefsin mahiyetiyle ilgili hâkim görüşün nefsin cismânîliği olduğu söylenebilir. Zira mütekaddimîn kelâmcıları, tesire açık olmamak ve faile muhtaç olmamak gibi Allah’a benzeşme anlamına gelebilecek sıfatlara sahip olduğunu düşündükleri soyut varlıklara şiddetle karşı çıkmışlardır. Öyle görünüyor ki bu kelâmcılar, bir varlığın soyut olmasının onu failden müstağni kıldığını düşündüklerinden soyut varlıkları Allah’a benzetme tehlikesinden kaçınmak istediler. Diğer taraftan onlara göre, hâdis varlıklarda mütehayyiz (cisim veya atom) ve mütehayyize yerleşen (araz) dışında bir kategorinin bulunduğuna dair hiçbir delil yoktur. Delilin bulunmaması medlûlün de reddedilmesini gerekli kılmaktadır. Dolayısıyla delili bulunmadığından soyut varlıkların nefyedilmesi gerekmektedir. ${ }^{41}$ Âmidî̀ye göre, Mu'tezile ve çoğu Eş‘arî (kesîrun min așhâbinâ) bu yöntemle soyut varlıkları nefyetmişlerdir. ${ }^{42}$ Teftâzânî de nefsin soyut olamayacağına dair ileri sürülen dört delile yer verdikten sonra bazen de onun soyutluğuna ilişkin bir delilin bulunmamasının soyutluğun nef-

tanımını ana hatlarıyla kabul etmekle birlikte Platon'da olduğu gibi nefsi gayri maddî bir cevher kabul etmişlerdir. Türker, "Nefis", 529; Atilla Arkan, "Psikoloji: Nefis ve Akıl”, İslâm Felsefesi: Tarih ve Problemler, ed. M. Cüneyt Kaya (İstanbul: İSAM Yayınları, 2013), 574-5.

38 Râzî, Metâlib, VII, 38; Ebû Abdullah Fahreddin Muhammed b. Ömer Fahreddin er-Râzî, Nihâyetü'l-ukûl, thk. Saîd Fûde (Beyrut: Dârü'z-Zehâir, 2015), IV, 143-4; Râzî, el-Erbaî̀n, II, 27.

39 Teftâzânî, Şerhu'l-Makâsıd, II, 211. Şerhu'l-Makâsıd'da Teftâzânî, bu görüşün "muhakkik filozoflar ve İslâm ehli” tarafından benimsendiğini belirtmektedir. Bu görüşü "muhakkik filozoflar”a nispet etmesi, Teftâzânînin de bu görüşü benimsediğine ilişkin bir ima olarak yorumlanamaz. Zira Teftâzânî kendisini filozof olarak değil bir kelâmcı olarak görür. Diğer taraftan soyut nefis tek bir görüş olmakla birlikte cismânî nefis altında on farklı görüş bulunmasından dolayı Teftâzânî, cismânî nefis görüşlerinden her birini zikrederken "denildi (kîle)" lafzını kullanmaktadır. Bu lafzı kullanması da onun cismânî nefis görüşleri arasında zikredip kelâmcıların çoğunluğuna nispet ettiği "latif cisim" ve "aslî parçalar" görüşlerini reddettiği anlamina kesinlikle gelmemektedir. Zira makalenin çeşitli yerlerinde de değinildiği gibi o, bu ikisinin kelâmcıların itimat edilen görüşleri olduğunu açıkça ifade etmektedir. Bk. Teftâzânî, Şerhu'l-Makâsıd, II, 30, Teftâzânî, “Makâsıd”, II, 29; Teftâzânî, Tehzîb, 71.

40 Teftâzânî, Tehzîb, 71.

41 Râzî, Metâlib, VII, 25; Ebü'l-Hasan Seyfüddin Ali b. Muhammed Âmidî, Ebkârü’l-efkâr fî usûli'd-dîn (Kahire: Dâru'l-Kütüb ve'l-Vesâiki'l-Kavmiyye, 2004), III, 28; Teftâzânî, Şerhu'l-Makâsıd, II, 31. 
yedilmesine delil getirildiğini belirtir. Ancak ona göre bu delil, çok zayıf bir ilkeye dayanmaktadır. Zira aynı ilkeden hareketle onun cismânî olduğuna dair bir delilin bulunmadığı, dolayısıyla nefsin cismânîliğinin reddedilmesi gerektiği söylenerek muaraza yapılabilir. ${ }^{43}$

Daha önceleri bazı kelâmcılar tarafından savunulan "delilin yokluğunun medlûlün nefyini gerektirdiği" şeklindeki ilkenin terkedilmesi, ${ }^{44}$ "sıfatlardaki benzerliğin zâtta benzerliği gerektirdiği” yönteminin revize edilmesi ve felsefî kavramların kelâma girmesi, mütekaddimîn kelâm düşüncesinde fazla kabul görmeyen soyut nefis anlayışının müteahhir dönemde yaygınlaşmasına zemin hazırlamıştır. ${ }^{45}$ Söz gelimi imkân anlayışının kelâma dâhil edilmesi sayesinde soyut olsa da, bir varlığın zâtı gereği mümkün varlık olabileceği ve bu imkânın onu faile muhtaç olmaktan müstağni kılmadığı söylenebilmiştir. Daha da önemlisi Râzînnin ifade ettiği üzere olumsuzlamalardaki (selb) benzerliklerin zâtta benzeşmeyi gerektirmediği söylenerek mümkün varlığın soyutluğunun onu Allah'ın zâtına benzer kılmadığı dile getirilmiştir. ${ }^{46}$ Soyut nefis anlayışına yönelik eleştirilerin müteahhir dönemde geçerliliğini yitirmesinin yanı sıra dönemin kelâmcıları, bu görüşün dinin asıllarına zarar vermek bir yana öldükten sonra diriliş gibi bazı temel inanç esaslarının temellendirilmesine zemin hazırladığını ve inkâr edenlerin eleştirilerine maruz kalmayacak şekilde haşri açıklama imkânı sağladığını düşünmüşlerdir. ${ }^{47}$

Bazı eserlerinden hareketle soyut nefis görüşünü savunduğu iddia edilmekle birlikte $^{48}$ Râzînin temel eserlerinde nefisle ilgili görüşlerini detaylı bir şekilde inceleyen Altaş, onun soyut nefis görüşünü savunduğunu iddia etmenin teoloji, fizik, metafizik ve epistemoloji gibi alanlardaki görüşlerini tutarlı bir şekilde izah etmede sorunlara yol açtığını ifade etmekte ve hayatının herhangi bir döneminde bu

Teftâzânî, Şerhu'l-Makâsıd, II, 31. Cürcânî de bir kısım kelâmcıların bu zayıf yöntemi kullandıklarını belirtmekte ancak onların kimler olduğunu tasrih etmemektedir. Seyyid Şerif Cürcânî, Şerhu'l-Mevâkıf: Mevâkıf şerhi (metin-çeviri), çev. Ömer Türker (İstanbul: Türkiye Yazma Eserler Kurumu Başkanlığ1 Yayınlar1, 2015), I, 404.

44 Âmidî̀nin bu yönteme yönelik eleştirileri için bk. Âmidî, Ebkârü'l-efkâr, I, 208-10.

45 Ömer Türker, "Kelam ve Felsefe Geleneklerinin Kesişim Noktasında Seyyid Şerif Cürcânî”, İslâm Düşüncesinde Süreklilik ve Değişim: Seyyid Şerif Cürcânî Örneği, ed. M. Cüneyt Kaya (İstanbul: Klasik Yayınları, 2015), 14-5.

46 Râzî, Metâlib, VII, 26; Altaş, "Fahreddîn er-Râzîye Göre İnsanın Mahiyeti ve Hakikati”, 167-8.

47 Râzî, Nihâyetü'l-ukûl, IV, 145; Teftâzânî, Şerhu'l-Makâsıd, II, 211. Teftâzânî de soyut cevher anlayışının meâdın imkânı konusunda güçlü bir teori olduğunu kabul etmektedir. Bk. Teftâzânî, Şerhu'l-Makâsıd, II, 214.

48 Râzînnin Mebâhis'te soyut nefis anlayışını savunduğuna dair bir çalışma için bk. Muhammad Fariduddin Attar, "Fahr al-Din al-Razi on the human soul: a study of the psychology section of al-Mabahith al-masriqiyya fi'ilm al-ilhahiyyat wa-l-tabi'iyyat" (Yüksek Lisans Tezi, Montreal, McGill University Institute of Islamic Studies, 2014), 53-83. 
görüşü açıkça savunmadığını belirtmektedir. Dolayısıyla Altaş'a göre temel eserleri dikkate alındığında onun latif cisim anlayışını savunduğunu söylemek daha makul gözükmektedir. ${ }^{49}$

Müteahhir dönemde Seyfeddin el-Âmidî (ö. 631/1233) ${ }^{50}$, Kâdî Beyzâvî (ö. 685/1286) ${ }^{51}$, Şemseddin el-İsfahânî (ö. 749/1349) ${ }^{52}$, Adudüddin el-Îcî (ö. 756/1355) ${ }^{53}$ ve Seyyid Şerif Cürcânî (ö. 816/1413) ${ }^{54}$ gibi önde gelen Eş'arî kelâmcılarının nefsin hakikati konusundaki görüşlerine dair kesin bir hükme varmak zor olsa da eserlerinde konuyu ele alma yöntemleri ve varlıklara dair taksimleri bu düşünürlerin soyut nefis görüşünü benimsediklerini ima etmektedir. Ancak bu düşünürlerin nefis konusundaki görüşlerini düşünce sistemlerinden hareketle netliğe kavuşturmak daha isabetli olacaktır.

Buraya kadar ele alınan başlıklarda aslında Teftâzânînnin eserlerinin nefisle ilgili bölümlerinde nefsin hakikati meselesini nasıl ele aldığı anahatlarıyla incelenmiştir.

Altaş, "Fahreddîn er-Râzîye Göre İnsanın Mahiyeti ve Hakikati”, 139-95.

50 Nefsin soyutluğu görüşünü Yunan filozoflarından bir grup, İslâm filozofları ve tenâsühçülere nispet eden Âmidî de bu görüşün dayandığı on beş tane delil zikredip bunlara bir eleştiri veya itiraz yöneltmez. Âmidînin yer verdiği bu delillerin tamamında nefsin cismânî kabul edilmesi halinde ortaya çıkacak sorunlardan hareketle soyut nefis görüşü savunulmuştur. Diğer bir ifadeyle bunlar, aynı zamanda nefsin cismânîliğini reddetmeye yönelik deliller olarak görülebilir. Eğer cismânî nefis anlayışını savunsaydı onun en azından bunlara cevap vermesi beklenirdi. Bk. Âmidî, Ebkârü'l-efkâr, IV, 276-81.

51 Bu çerçevede söz gelimi akıl ve naklin nefsin soyutluğu görüşüne delâlet ettiğini söyleyen Beyzâvî, daha sonra bu aklî ve naklî delilleri sıralar. Zikrettiği aklî delillerden sadece bir tanesinin zayıf olduğunu belirten Beyzâvî, naklî delilleri tek tek zikrettikten sonra baştaki ifadesinin aksine bunların nefsin soyutluğuna değil onun bedenden başka bir şey olduğuna delâlet ettiğini söyler. Beyzâvî, naklî delillerin soyut nefsin varlığını gösterdiği konusunda çekincelerini ifade etmekle birlikte naklî delillerin geneli ile ilgili herhangi bir olumsuz açıklamada bulunmaz. Nefsin soyutluğu görüşünü detaylı bir şekilde açıkladıktan sonra nefsin cismânîliğine dair görüşleri sıralayan Beyzâvî, bunların delillerini zikretmediği gibi onlarla ilgili herhangi bir değerlendirmede de bulunmaz. Bk. Kâdî Nâsırüddin Ebû Saîd Abdullâh b. Ömer Beyzâvî, Tavâli'u'l-envâr, thk. Süleyman Abbas (Beyrut ve Kahire: Dârü'l-Cîl -el-Mektebetü'l-Ezheriyye Li'tturâs, 1991), 150-53. Beyzâvî’nin çağdaşı Şî̂-İmâmî kelamcı Tûsî soyut nefis görüşünü açık bir şekilde savunmaktadır. Bk. Ebû Ca'fer Nasîrüddin Muhammed b. Muhammed Tûsî, Tecrîdü'l-akâid, thk. Abbas Muhammed Hasan Süleyman (İskenderiye: Dâru'l-Ma'rifetü'l-Câmiiyye, 1996), 95-6.

52 Mahmûd b. Abdurrahman Şemsüddîn el-İsfahânî, Tesdîdü'l-kavâid fî şerhi Tecrîdü’l-akâid, nşr. Hâlid b. Hammâd el-Advânî (Beyrut: Dârü'l-Ziyâ', 2012), I, 679-89.

53 Îcî, soyut nefis görüşünü zikrettikten sonra bu görüşün delillerine ve bu delillere yönelik itirazlara yer verir. Daha sonra nefsin cismânîliği görüşüne geçen düşünür, bu çerçevede ileri sürülen alt görüşleri sıralar. Ancak o, nefsin cismânîliği kapsamında bu görüşlerin hiçbirinin delilini zikretmediği gibi yer verilen bu görüşlerin hiçbirine dayanılamayacağını da açıkça ifade eder. Bk. Adudüddin Îcî, el-Mevâkıf fî ilmi'l-kelâm (Beyrut: Âlemu'l-Kütüb, t.y.), 260. Türker, Îcî̀nin “cismânî nefis anlayışını savunanların zikrettiği görüşlerin hiçbirine güvenilemeyeceği”ni söylemesini de dikkate alarak onun nefsin soyut bir cevher olduğu görüşünü benimsediğini söyler. Bk. Ömer Türker, "Kelâm Geleneğinde Adudüddin el-Îcî: Kelâmın Bilimsel Kimliği Sorunu”, İslâm İlim ve Düşünce Geleneğinde Adudüddin el-Îtcî (İstanbul: İSAM Yayınları, 2017), 303.

54 Çağdaş araştırmacılar genellikle Seyyid Şerif Cürcânînin de nefsin soyutluğu konusunda filozoflarla hem fikir olduğunu savunmaktadırlar. Bk. Türker, "Kelam ve Felsefe Geleneklerinin Kesişim Noktasında Seyyid Şerif Cürcânî”, 17. 
Görüldüğü gibi Teftâzânî, nefsin hakikati konusunda kendisinden önce ileri sürülmüş yaklaşımları yeniden yorumlamakta, ancak kendisinin hangi görüşü savunduğunu açık bir şekilde ifade etmemektedir. Ona göre, soyut nefis görüşü, farklı hakikate sahip latif cisim, aynı hakikate sahip latif cisim ve aslî parçalar görüşü insanî nefsin hakikati konusunda güvenilir görüşlerdir. Bunlardan herhangi birinin kesin olarak doğru olduğunu veyahut da kesin olarak yanlış olduğunu ortaya koyacak herhangi bir delil bulunmamaktadir.

Teftâzânî, nefsin hakikati konusundaki iki ana yaklaşım olarak gördüğü "cismânî nefis görüşü" ile "soyut nefis görüşü"ne dayanak oluşturan başlıca argümanları da analiz etmektedir. Cismânî nefis taraftarlarının dayandığı beş argümanı zikreden Teftâzânî, ${ }^{55}$ bunlardan dördünün temelde "soyut nefsin tikellerle doğrudan bir ilişki ve irtibatının olamayacağı" varsayımından hareketle ortaya konulduğunu düşünür ve bu doğrultuda söz konusu argümanlara itiraz yöneltir. Söz gelimi, bir hükümde bulunan öznenin hükmün iki tarafını da idrak etmesi gerektiğinden nefsin de "Bu ateş sıcaktır” şeklindeki gibi bir hükme varabilmesi için hem cismânî tikeli (bu ateş) hem de tümeli (sıcak) idrak etmesi gerektiği yönündeki ilk argüman zikredilebilir. Ona göre, soyut nefis görüşünü savunmakla birlikte bir kişi, tikel olsun tümel olsun tüm bilinenleri idrak edenin nefis olduğunu söyleyerek bu argümana karşı koyabilir. Şu hâlde Teftâzânî’ye göre, cismânî nefis taraftarları tarafından getirilen deliller, esas itibariyle nefsin soyut bir cevher olduğu görüşünü değil, soyut nefsin tikellerle ve cismânî varlıklarla doğrudan bir ilişki içinde bulunmasının imkânsız olduğu görüşünü reddetmektedir. ${ }^{56}$ Teftâzânînin "nefsin zâtında soyut olması" ile "soyut nefisle cismânî tikellerin doğrudan ilişkisinin soyutlanması/olumsuzlanması" görüşlerine karşı tavrı birbirinden farklıdır.

Nefsin soyut bir hakikate sahip olmasının ve soyut nefsin cismânîlerle doğrudan bir ilişki içinde bulunmasının imkânsız görülmesi birbirlerinden farklı şeylerdir. İslâm filozofları her türlü çokluk ve maddîlikten münezzeh olan İlk İlke ile çokluğa sahip maddî varlıklar arasındaki ilişkiyi açıklamak için başvurdukları sudûrcu modeli epistemolojiye de taşıyarak gayri maddî olan soyut nefsin doğrudan tikelleri idrak edemeyeceğini savunmuşlardır. Dolayısıyla filozoflar açısından nefsin soyut olması, maddî tikellerle doğrudan ilişkili olmamayı zorunlu olarak gerekli kılmaktadır. Bu

55 Teftâzânî bunları zikrederken "bizim argümanlarımız şunlardır" şeklinde bir ifade kullanarak bir anlamda kendisinin de cismânî nefis görüşünü benimsediğini ima etmektedir. Bk. Teftâzânî, Şerhu'l-Makâsıd, II, 29-30; Teftâzânî, Tehzîb, 71.

56 Teftâzânî, Şerhu'l-Makâsıd, II, 30-31. Râzî de cismânî nefis görüşü taraftarlarına nisbet ettiği temel argümanların aslında soyut nefsin cismânî tikellerden soyutlanmasını reddeden deliller olduğuna işaret etmektedir. Bk. Murat Kaş, "Seyyid Şerîf Cürcânî̀de Zihnî Varlık”, (Doktora Tezi, İstanbul, Marmara Üniversitesi Sosyal Bilimler Enstitüsü, 2017), 103-5. 
yüzden filozoflar, soyut nefsin maddî tikelleri nasıl idrak ettiğini açılayabilmek için dış ve iç duyu güçlerine ihtiyaç duydular. Buna göre soyut nefis, tümelleri doğrudan idrak etmesine rağmen tikelleri ancak dış ve iç duyu güçlerinin aracılığıyla idrak edebilmektedir. Ölümle birlikte nefis bedeni terk ettiğinde ise artık onun tikelleri idrak etmesi imkânsız hale gelmektedir. ${ }^{57}$

Müteahhir dönemde soyut nefis görüşünü benimseyen veyahut benimsemese de en azından mümkün gören Eş'arî kelâmcılar, "soyut nefsin, tikelleri doğrudan idrak edemeyeceği” şeklindeki filozofların genel kabulüne şiddetle karşı çıkmış ve onu reddetmişlerdir. Zira onlara göre, soyut nefsin tikelleri doğrudan idrak edemeyeceği görüşü, kelâmın temel maksatları açısından kabul edilemez sonuçlara yol açmaktadır. Bu çerçevede nefsin soyut bir cevher olduğunu benimsemesine rağmen Gazzâlî, filozofların aksine onun maddî ve cismânî süreçlerden uzak olmadığını düşünmüş ve onunla cismânî varlıklar arasında sudûrcu bir anlayışla bir hiyerarşinin tatbik edilmesine kesin olarak karşı çıkmıştır. ${ }^{58}$ Râzî de bilginin bir izâfetten ibaret olduğunu ileri sürerek hem ilâhî zâtın tikelleri doğrudan bildiğini hem de soyut nefsin cismânî tikelleri doğrudan idrak edebildiğini temellendirme imkânı bulmuştur. ${ }^{59}$ Nefsin hem tümelleri hem de tikelleri idrak ettiğini savunan Râzî, "İki şey hakkında hüküm veren öznenin ikisini de bilmesi gerekir.” ilkesinin de buna delâlet ettiğini düşünmüştür. ${ }^{60}$

Dış ve iç duyu güçlerinin varlığını kabul eden Teftâzânî̀ye göre bu güçler cismânî tikellerin idrakinde sadece bir alet olarak işlev görmektedir. Dahası filozofların aksine o, cismânî tikellerin idrakinde bu güçlerin zorunlu olmadığını ve bunlar olmaksızın da nefsin idraklerinin gerçekleşebileceğini düşünmektedir. Yani ona göre insanda hiçbir duyu gücü olmasa da cismânî tikellere dair idrakler Allah tarafından nefiste yaratılabilir. O, nefsin zâtı bakımından soyut veya cismânî kabul edilmesinin akla veya nassa aykırılık teşkil etmediğini belirtmesine rağmen nefsin cismânî tikelleri doğrudan idrak edemeyeceğini söylemenin hem akla hem de naslara aykırı olduğunu ileri sürmektedir. Dolayısıyla ona göre, nefsin soyut kabul edilmesinde dinî ve aklî yönden herhangi bir sorun bulunmazken, cismânî tikelleri doğrudan idrak etmesini imkânsız görmek ve

57 Kaş, “Seyyid Şerîf Cürcânî'de Zihnî Varlık”, 103.

58 Kaş, "Seyyid Şerîf Cürcânî̀de Zihnî Varlık”, 81-84.

59 Kaş, “Seyyid Şerîf Cürcânî̀de Zihnî Varlık”, 101-105. Müteahhir dönemde soyut nefis görüşünün, tikellerin bilinmesi konusunda hangi problemlerle karşı karşıya kaldığı ve bu problemlerin nasıl çözüme kavuşturulmaya çalışıldığına dair karşılaştırmalı bir inceleme için bk. Ziya Erdinç, "Klasik Sonrası İslâm Düşüncesinde İnsanın Hakikatine İlişkin Önemli Bir Sorun: Soyut Nefis Tikelleri Bilebilir Mi?”, İnsanın, İnancın ve Mekanın İnşası-II: Değer ve Kavramlar Uluslararası ve Disiplinlerarası Ruh Sempozyumu Bildirileri ve Özetler Kitabı (Çanakkale: ÇOMÜ Yayınları, 2021), 429-446

60 Kaş, “Seyyid Şerîf Cürcânî’de Zihnî Varlık”, 101-105; Râzî, Muhassal, 229; Râzî, el-Mebâhisü'l-meşrikiyye fì ilmi'l-ilâhiyyât ve't-tabî'iyyât, thk. Muhammed Mu'tasım el-Bağdâdî (Beyrut: Dâru'l-Kitâbi'l-Arabî, 1990), I, 450; II, 345, 359. 
tikellerin idrak edilmesinde idrak güçlerinin zorunlu olduğunu savunmak kabul edilemez bir görüştür. Zira naslar, ölümle birlikte bedenini ve idrak güçlerini terk eden insanî nefsin cismânî tikelleri idrak etmeye devam ettiğini kesin olarak göstermektedir. Şu hâlde nefsin tikelleri doğrudan idrak edemeyeceğini söylemek dinî ilkelere aykırı düşmektedir. ${ }^{61}$ Ona göre aslında insandaki hiçbir bilgide duyu güçlerinin herhangi bir tesiri bulunmayıp Allah'ın var etmesi ve yaratmasıyla bilgiler meydana geldiğinden, müessir sebep Allah'tır. Yakma fiilinde ateşin sebepliliğinde olduğu gibi bilgilerin tamamının zâhirî sebebi ve asıl idrak edicisi nefis olup, duyu güçleri sadece birer alettir. ${ }^{62}$

Nefsin cismânîliğine ilişkin argümanları tartıştıktan sonra Teftâzânî, onun zâtında soyut olduğunu savunanların dayandıkları argümanlara geçer. Bu argümanlar genelde nefsin cismânî kabul edilmesi halinde bazı idraklerinin gerçekleşmesinin imkânsızlığından hareketle ortaya konulmaktadır. Ona göre, bunların tamamı belli bir idrak anlayışına dayanan argümanlar olup söz konusu idrak anlayışını savunmayanları bağlayıcı değildir. Diğer bir ifadeyle bu argümanlar, filozofların soyut nefis ve idrak konusundaki bazı ön kabullerine dayandığından zayıftırlar. ${ }^{63}$

Sonuç olarak hem soyut nefis hem de cismânî nefis görüşü taraftarlarının ortaya koyduğu delillerin zayıf olduğunu söyleyen Teftâzânî, bunlardan birinin doğruluğuna ilişkin kesin bir kanıt da zikretmez. Allah dışındaki soyut varlıkların mevcudiyetini kesin olarak reddeden mütekaddimîn kelâmcılarının aksine o, soyut varlıkların ne mevcudiyetini ne de imkânsızlığını gösteren bir delilin bulunmadığını düşünmektedir. Dolayısıyla ona göre, nefsin soyut bir cevher olduğu ne kesin delillerle ispatlanabilir ne de reddedilebilir. ${ }^{64}$

İnsanî nefsin hakikati konusunda latif cisim, aslî parçalar ve soyut nefis görüşlerini mümkün ve muteber teoriler olarak görmekle birlikte acaba onun benimsediği insanî nefis anlayışı hangisidir? Onun bu farklı görüşleri mümkün görmesi hepsini de benimsediği anlamına gelmemektedir. Zira nefsin hakikati konusundaki yaklaşımını etkileyen ve onunla ilişki olan çeşitli konularda kesin olarak benimsediği görüşleri tespit edilmek suretiyle Teftâzânî’nin bu konudaki görüşü hakkında da kesin bir sonuca varılabilir. Nitekim cismin madde-suretten mi yoksa atomlardan mı meydana geldiği konusunu incelediği kısımda Teftâzanî, her iki tarafın delillerinin zayıf olduTeftâzânînnin eleştirilerinin detaylı bir analizi için bk. Ziya Erdinç, "Teftâzânîde Bilgi Teorisi" (Doktora Tezi, Sakarya, Sakarya Üniversitesi Sosyal Bilimler Enstitüsü, 2019), 183-194.

62 Sa'düddin Mes'ud b. Ömer b. Abdillah el-Herevî et-Teftâzânî, Şerhu'l-Akâidi’n-Nesefiyye, nşr. Ahmed Hicâzî es-Sekâ (Kahire: Mektebetü'l-Külliyâti'l-Ezheriyye, 1988), 15.

63 Teftâzânî, Şerhu'l-Makâsıd, II, 31-5.

64 Teftâzânî, Şerhu'l-Akâid, 27. 
ğunu söylemesine rağmen madde-suret teorisinin inanç konularında kabul edilemez birtakım sonuçları olduğuna dikkat çeker. Böylece o, bu tür sonuçlarından ötürü madde-suret teorisini benimsemediğini ifade etmeye çalışır. ${ }^{65}$ Ancak madde-suret teorisinden farklı olarak soyut nefis görüşünün inanç konularına zarar verdiğine dair herhangi bir açıklamada bulunmaz.

\section{Teftâzânî'nin İnsan Hakikati Konusundaki Görüşü}

Bir taraftan çalışmanın önceki başlıklarında doğrudan nefisle ilgili ifadeleri diğer taraftan sonraki başlıkta ayrıntılı bir şekilde incelenecek olan epistemoloji, fizik, metafizik ve teoloji konularında insanın hakikatiyle ilişkili açıklamalarından hareketle Teftâzânînin insanın mahiyetine dair yaklaşımı burada anahatlarıyla zikredilecektir. Sonraki başlıkta ise burada zikredilen yaklaşımın onun düşünce sisteminden hareketle nasıl tespit edildiği ortaya konulmaya çalışılacaktır.

Teftâzânî, kendi düşüncesine zemin hazırlamak ve onu temellendirmek amacıyla çoğu zaman tevarüs ettiği geleneği yeniden yorumlayarak aktarır. Bu çerçevede insanın hakikatine ilişkin görüşünü ortaya koymak için öncelikle kelâmc1ların çoğunluğuna nispet edilen bünye görüşünün "insanî nefsin bedenine özdeşliği" şeklinde yorumlanmasına karşı çıtığı ifade edilmişti. Böylece o, nefsi bedene indirgeyen aşırı cisimsel nefis anlayışını tamamen reddedip ruhun bedenin ötesinde bulunmasını apaçı bir ilke olarak vazetmek suretiyle nefis görüşünü bir anlamda soyut nefis anlayışına yaklaştırır. Ancak öte yandan o, ruh-beden arasında varlık yapısı bakımından bir düaliteden kaçınmak için de her ikisinin cismânî olduğunu savunur. Daha sonra ise bedenin ötesindeki ruhun hakikatine ilişkin görüşler çerçevesinde kelâmc1lara nisbet ettiği latif cisim ve aslî parçalar görüşlerine de insan tasavvurunda yer verir. İnsanî nefsin hakikatini latif cisimden ibaret kabul eden Teftâzânî, bedenin hakikatini temellendirmek için de aslî parçalar görüşünden faydalanır. Şu hâlde Teftâzânînin düşünce sisteminden hareketle onun insana dair tasavvurunu aşağıdaki dört unsur çerçevesinde özetlemek mümkündür:

(i) İnsanî nefis: İnsan ruhu ve düşünen nefis olarak da isimlendirilen insanî nefis, diğer cisimlerle benzeşik (mütemâsil), yani hakikat bakımından aynı olan latif bir cisimdir. İnsanı insan yapan ve onun özünü oluşturan, bu latif cisimdir. Diğer bir ifadeyle insanı insan yapan sadece latif cisim olan insanî nefistir. Bazı kelâmcılar bu latif cismin hakikat bakımından diğer cisimlerden farklı olduğunu savunurken Teftâzânînnin yaklaşımında ise bu latif cisim diğer cisimlerle aynı hakikate sahiptir. 
Teftâzânî’ye göre hem filozofların soyut nefis görüşü hem de kelâmcılar tarafından benimsenen latif cisim ve aslî parçalar görüşleri konuyla ilgili mümkün teorilerdir. Ancak bununla birlikte Teftâzânî’nin meseleyi tartışırken kelâmcılara nisbet ettiği cismânî nefis görüşlerinin temellendirilmesi bağlamında zikredilen delilleri "Bizim delillerimiz şunlardır" diyerek sahiplenmesi cismânî nefis görüşünü benimsediğine bir işaret sayılabilir. ${ }^{66}$ Ancak o, filozofların ve kelâmcıların nefsin hakikati konusundaki görüşlerini temellendirmek için zikrettiği görüşleri detaylı bir şekilde inceledikten sonra her iki tarafın delillerinin da zayıf ve iknâî olduğunu belirtir ve yeni bir delil zikretmez. ${ }^{67}$ Özellikle belirtmek gerekir ki, müteahhirîn dönemi kelâmının dili dikkate alındığında Teftâzânînin kelâmcıların görüşlerini sahiplendiğini gösteren ibareler kullanması elbette tek başına onun görüşünü ortaya koymak için yeterli olmaz. Bu yüzden bu çalışmamızda onun çeşitli konulardaki görüşleri de dikkate alınarak "aynı hakikate sahip latif cisim" görüşünü benimsediği sonucuna ulaşılmıştır. Zira her ne kadar Teftâzânî, nefsin hakikati konusunda "doğrusu şudur" şeklinde kesin bir ifade kullanmasa da bu kesin ifadeyi kullandığı konulardaki görüşleri bir bütün olarak ele alındığında yukarıda zikredilen sonuca rahatlıkla varılabilir.

(ii) Aslî parçalar: Bedenin parçaları aslî ve fazlalık parçalar olmak üzere iki kısma ayrılmaktadır. Bedenin aslî parçaları insanî nefsin değil ancak bedenin özünü oluşturur. Bu parçalar insan ömrünün başından sonuna kadar onun bedeninden ayrılmayan ve ölüm ötesi hayatta bedensel dirilişe temel oluşturacak cüzlerdir.

(iii) Fazlalık parçalar: Bedeni meydana getiren fazlalık parçalarla kastedilen, insanın ömrünün belli bir döneminde onun bedeninde bulunmuş parçalardır. Bedensel dirilişte insan fertlerinin bedenlerine bu fazlalık parçaların tamamı ve aynısı değil onların benzerleri döndürülecektir.

(iv) Hayvanî ruh: Buharımsı yapıdaki hayvanî ruh da latif bir cisim olup kesif olan insan bedeni ile latif yapıdaki insan ruhu arasındaki irtibatı sağlamaktadır.

\section{Teftâzânî'nin Düşünce Sisteminde İnsanın Hakikati}

Teftâzânî'nin insanın hakikatine dair tasavvurunu meydana getiren zikredilen dört unsur, onun epistemoloji, fizik, ontoloji ve teoloji konularında açık bir şekilde benimsediği tespit edilen görüşlerinden hareketle çıkarılmıştır. 
Daha önce de ifade edildiği gibi Teftâzânî, insanî nefsin hakikati konusunda soyut nefis, aslî parçalar ve latif cisim anlayışlarını itimat edilen görüşler olarak görmekte ve bunları ön plana çıkarmaktadır. Bu bölümde Teftâzânî’nin düşünce sisteminin nefis anlayışıyla ilişkili boyutları incelenirken her bir konudaki görüşlerinin tamamının soyut nefis veya aslî parçalar anlayışıyla uyumsuz olduğu iddia edilmemektedir. Ancak onun bazı konulardaki görüşlerinin soyut nefisle diğer konulardaki görüşlerinin ise aslî parçalar anlayışıyla uyumsuz olduğu tespit edilmiştir. Bununla birlikte "diğer cisimlerle aynı hakikate sahip latif cisim" anlayışının ise onun düşünce sistemindeki ilişkili tüm görüşleriyle uyumlu olduğu ortaya konulmaya çalışılmıştır. Bu çerçevede söz gelimi, onun fizik anlayışı ve meleklerin mahiyeti konusundaki görüşlerinden hareketle soyut nefis anlayışına sahip olamayacağı; kabir hayatı ve haşirle ilgili görüşlerinden yola çıkılarak da aslî parçaları insanî nefsin hakikati olarak görmediği sonucuna ulaşılmıştır. Diğer taraftan ontoloji ve epistemoloji konusundaki görüşleri ise onun latif cisim görüşünün karşı karşıya kaldığı sorunları çözmek için mütekaddimîn Eş‘arîlerinin genel kabulü olan bazı önermeleri reddettiği veya yeniden yorumladığı üzerinde durulmuştur. Ontoloji ve epistemolojideki bu tutumunun aslında onun insanî nefsin hakikatini latif cisim olarak görmesinden kaynaklandığını düşünüyoruz.

\subsection{Fizik Anlayışı}

İslâm düşünürleri, varlık anlayışlarına uygun olarak altında tüm mevcutların sınıflandırılabileceği varlık taksimleri geliştirmişlerdir. Düşünürlerin varlık taksimleri, onların insanî nefislerin hakikatine dair benimsedikleri görüşler konusunda da önemli bilgiler içermektedir.

Meşşâî ve İşrâkî filozofların varlık taksimleri, Allah dışındaki gayri cismânî varlıkların dâhil edilebileceği bir kategoriyi de ihtiva etmektedir. Varlıkları zorunlu ve mümkün şeklinde iki kısma ayıran Meşşâî filozoflar, onun parçası olmaksızın bir konuda bulunan varlığı "araz", bir konuda bulunmayan varlığı ise "cevher" olarak isimlendirmişlerdir. Cevherler ise cisim, madde, suret, akıl ve nefis olmak üzere beş kategoriye ayrılmıştır. Bunlardan cisim, madde ve suret cismânî iken akıl ve nefis ise soyut cevherlerdir. Soyut cevherlerden nefsin cisimle bir tasarruf ve tedbir ilişkisi bulunmakla birlikte akıl her yönden cisimden uzak cevherlere verilen isimdir. ${ }^{68}$ İşrâkîlere göre ise, varlıklar hey'et ve cevher olmak üzere iki kısma ayrılır. Cevherlerin yer kaplayıcı olanları cirmânî, yer kaplayıcı olmayanları ise ruhânî şeklinde isimlendirilir. Buna göre cisim, cirmânî cevherler kısmında yer alırken nefis ve akıl 
da ruhânî cevherler kategorisinde yer almaktadır. Dolayısıyla hem Meşşâî hem de İşrâkî varlık taksiminde insanî nefisler, gayri cismânî ve soyut cevherler kategorisinde kabul edilmiştir. ${ }^{69}$

Mütekaddimîn dönem kelâmcıları genel olarak cismânî nefis anlayışına sahip olduklarından ve Allah'tan başka gayri cismânî varlıkların bulunmasını imkânsız gördüklerinden varlık taksiminde soyut varlıkların dâhil edileceği bir kategoriye yer vermemişlerdir. Onlara göre varlıklar kadîm ve hâdis olmak üzere iki kısma ayrılmaktadır. Hâdis varlıklar ise cevher (mütehayyiz/yer kaplayıcı) ve araz (mütehayyize yerleşen) olmak üzere kısımdır. Bölünebilen cevherlere cisim, bölünemeyen cevherlere ise cevher-i ferd denilmiştir. Gazzâlî ile birlikte kelâmî düşüncede soyut nefis anlayışı yaygınlaşmaya başlayınca kelâmcıların atomcu fizik anlayışlarına uygun olarak ortaya koydukları varlık taksiminde de bazı değişiklikler yapılmıştır. Bu çerçevede hâdis varlıkların kısımlara ayrılmasında mütehayyiz ve mütehayyize yerleşenden başka "ne mütehayyiz ne mütehayyize yerleşen" şeklinde ifade ettikleri üçüncü bir kısım daha ihdas edilmiştir. Ancak bazı kelâmcılar da taksimlerinde bir ihtimal olarak bu üçüncü kısmı zikrettikten sonra bunun imkânsızlığını ortaya koymaya çalışmışlardır. ${ }^{70}$

Teftâzânînnin varlık taksiminde hâdis varlıklar için doğrudan yer kaplayıcı olan cevher ile dolaylı olarak yer kaplayıcı olan araz olmak üzere iki kısım bulunmaktadır. Cevher ise eğer bölünüyorsa cisim, bölünmüyorsa cevher-i ferddir. ${ }^{71}$ Teftâzânînin en son telif ettiği kelâm eseri Tehzîb'de yer alan taksimde Allah dışındaki soyut varlıkların dâhil edilebileceği bir kısım bulunmamaktadır. Eğer insanî nefisleri soyut varlıklar olarak kabul etseydi onun, tüm varlıkları sınıflandırdığı varlık taksiminde onların dahil edileceği bir kategoriye yer vermesi beklenirdi. Şerhu'l-Makâsıd'da kelamcılara nispet ettiği varlık taksiminde hâdis olan soyut varlıkların dâhil edilebileceği "ne mütehayyiz ne mütehayyize yerleşen" şeklinde üçüncü bir kısım daha zikreder. Ancak burada delillerinin zayıflığından dolayı hâdis olan soyutların varlıklarının sabit olmadığını ve bu yüzden de kelâmcıların onu varlıkların kısımlarından biri olarak görmediklerini belirtir. ${ }^{72}$

Teftâzânînin benimsediği varlık taksimi, aslında onun madde-suret teorisini değil atomculuğu kabul ettiğini de göstermektedir. Nitekim o, İslâmî ilkelerin kabul

70 Beyzâvî, Tavâli'u'l-envâr, 76; Kâdî Nâsırüddin Ebû Saîd Abdullâh b. Ömer Beyzâvî, Misbâhü'l-ervâh fî usûli'd-dîn, thk. Saîd Fûde (Ammân: Dârü'r-Râzî, 2007), 85.

71 Teftâzânî, Tehzîbu'l-mantık ve'l-kelâm, 35-6, 56-7.

72 Teftâzânî, Şerhu'l-Makâsıd, I, 173-4. 
edilmesi ve savunulmasında atomcu fizik anlayışının olumlu katkısına işaret etmektedir. ${ }^{73}$ Ancak farklı atomculuk anlayışlarının bulunduğu bilinmektedir. Teftâzânînin hangi atomculuk anlayışını kabul ettiğinin tespit edilmesi, onun farklı cismânî nefis anlayışlarından hangisini benimsediğini belirlemek açısından önem taşımaktadır. Zira Teftâzânî̀nin insanî nefsin hakikatine dair aktardığı "farklı hakikate sahip latif cisim" ve "aynı hakikate sahip latif cisim" görüşlerinden her biri farklı bir atomculuk anlayışıyla uyumlu anlayışlardır. Teftâzânî bu iki cismânî nefis anlayışından hangisini benimsediğini açık bir şekilde ifade etmiyor. Ancak onun kabul ettiği atomcu anlayış belirlendiğinde bu hususu netleştirmek mümkün olacaktır.

"Farklı hakikate sahip latif cisim görüşü” incelendiğinde bu görüşün onun fizik anlayışına aykırı olduğu görülecektir. Zira Râzînnin de belirttiği gibi bu görüşün diğerinden en önemli farkı, latif cisim olduğu söylenen ruhun hakikat bakımından diğer cisimlerden farklı kabul edilmesine dayanmasıdır. Halbuki cisimlerin hakikat bakımından farklı olduğu, Teftâzânî tarafından ısrarla reddedilen bir husustur. Meselenin daha iyi anlaşılması için kelâmcıların fizik anlayışlarına muhtasar bir şekilde değinmek faydalı olacaktır.

Türsel sureti reddedip âlemin fiziksel yapısını atom ve arazlardan hareketle açıklayan kelâmcıların, hâdis varlıklar arasındaki farklılaşma ve benzerliklerin izahında dayandıkları atomcu anlayışları genel hatlarıyla üç kısma ayırmak mümkündür:

(i) Benzeşik Atomlardan Oluşmuş Benzeşik Cisimler: ${ }^{74} \mathrm{Bu}$ atomcu anlayışta atomların da onlardan meydana gelen cisimlerin de aynı hakikate sahip olduğu (mütemâsil/benzeşik) savunulmaktadır. ${ }^{75}$ Çünkü buna göre cisimleri meydana getiren atomların tamamı benzeşik (mütemâsil) bir yapıdadır. Atomların tamamı cevher olmak, mütehayyiz olmak ve arazları kabul etmek gibi nefsî sıfatlarda ortak olduğundan benzeşik kabul edilmişlerdir. Arazların ise cismin hakikatinin meydana gelmesinde herhangi bir etkisi bulunmadığından benzeşik atomlardan meydana gelmiş cisimler de doğal olarak hakikat bakımından aynıdır. Her ne kadar cisimlere

73 Teftâzânî, Şerhu'l-Akâid, 25; Teftâzânî, Tehzîbu'l-mantık ve'l-kelâm, 60.

74 Cisimlerin benzeşikliğini kabul etmek, zorunlu olarak atomların da benzeşikliğini kabul etmeyi gerektirir. O yüzden benzeşik cisimler görüşü tek başına kullanıldığında atomların da benzeşikliğini ifade eder.

75 Ebû Bekr Muhammed b Hasan el-Ensârî İbn Fûrek, Mücerredü makâlâti'ş-şeyh Ebi'l-Hasan el-Eş'arî, thk. Daniel Gimaret (Beyrut: Dârü'l-Meşrik, 1987), 265-66; Ebü’l-Hasen Kâdî Abdülcebbâr, Şerhü'l-Usûli'l-hamse, nşr. Abdülkerim Osman (Kahire: Mektebetü Vehbe, 1988), 92, 219-20; İmâmü'l-Haremeyn Ebü'l-Meâlî Rüknüddîn Abdülmelik b. Abdillâh el-Cüveynî, eş-Şâmil fî usûli'd-dîn, nşr. Ali Sâmî en-Neşşâr vd. (İskenderiye: Münşeetü'l-Maârif, 1969), 153-5; İmâmü'l-Haremeyn Ebü'l-Meâlî Rüknüddîn Abdülmelik b. Abdillâh el-Cüveynî, el-İrşâd ila kavâtii'l-edilleti fì usûli'l-i'tikad, thk. Muhammed Yusuf Mûsâ (Kahire: Mektebetü'l-Hancî, 1950), 38-39; Ebü'l-Yüsr Muhammed b Muhammed b Hüseyin Pezdevî, Usûlü'd-dîn, thk. Hans Peter Linss (Kahire: el-Mektebetü'l-Ezheriyye li't-Turâs, 2003), 34-35; Âmidî, Ebkârü'l-efkâr, III, 36. 
ilişmeleri dolayısıyla arazlar cisimlerin birbirlerinden farklılaşmasına yol açsa bu, hakikat bakımından değil, arazlar yönünden bir farklılaşmadır. Dolayısıyla atomların tamamı aynı hakikate sahip olduğundan ve cisimler de atomlardan meydana geldiğine göre cisimlerin de benzeşik olmaları gerekmektedir. ${ }^{76}$

Teftâzânî̀ye göre, atomların yukarıda zikredilen sıfatlar dışında herhangi bir nefsî niteliği yoktur. Dolayısıyla atomlardaki ağırlık ve şekil gibi sıfatlar nefsî yani birincil niteliklerden değildir. Atomların kendinde bir ağırlıkları bulunmamasından dolayı az atomdan meydana gelen bir cismin ağırlığı daha fazla atomdan meydana gelmiş bir cismin ağırlığından fazla olabilir. Eğer her bir atomun belirli bir ağırlığı bulunduğu iddia edilirse sayıca fazla atoma sahip cismin zorunlu olarak daha ağır olması gerekecektir. ${ }^{77}$

Atomların mütemâsil olduğunu ifade eden Teftâzânî onlardan meydana gelen cisimlerin de benzeşik olduğunu savunur. Ona göre cisimlerin genel hükümlerinden birisi de onların benzeşik olması, yani aynı hakikate sahip olmasıdır. Benzeşik olduklarından dolayı biri hakkında ne mümkünse diğeri hakkında da aynısı mümkündür. Dolayısıyla onlar arasındaki farklılık, Fâil-i Muhtar'ın kudretine dayanan arazlar aracılığılla gerçekleşmektedir. ${ }^{78}$ Cisimlerin hakikat yönünden aynı oldukları ve farklılıkların ise arazlardan kaynaklandığını belirten Teftâzânî, Kâdir-i Muhtâr'ın isbâtı, nübüvvetle ilgili çok sayıda mesele ve meâd gibi birçok İslâmî esasın bu ilkeden hareketle temellendirildiğini belirtir. ${ }^{79}$ Bu bağlamda örneğin miraç hadisesinin yakaza halinde ve cesetle meydana geldiğini kesin olarak belirten Teftâzânî, bu mucizenin imkânını cisimlerin benzeşik olması teorisiyle açıklar. Ona göre, gökyüzü de yeryüzü gibi benzeşik cisimlerden oluştuğu için bir kimse yeryüzündeki cisimleri yararak geçip gittiği gibi gökyüzünü de yarıp gidebilir. ${ }^{80}$ Aslında bu ilke, mucizelerin tamamının temellendirilmesinde merkezî bir konuma sahiptir. Söz gelimi göksel cisimlerin kendilerinde bulunan türsel suretten dolayı yarılma ve birleşmeyi kabul etmelerinin mümkün olmadığını savunan Meşşâî filozofların aksine, cisimlerin benzeştiğini savunan Teftâzânî̀ye göre, ay-altındaki cisimler birleşme ve ayrışmayı kabul ettiği

Kâdî Abdülcebbâr, Şerhü'l-Usûli'l-hamse, 92, 220; Cüveynî, eş-Şâmil, 153-55; Pezdevî, Usûlü'd-dîn, 34-35; Âmidî, Ebkârü'l-efkâr, III, 103-4.

77 Teftâzânî, Şerhu'l-Makâsıd, I, 206, 375.

78 Teftâzânî, Şerhu'l-Makâsıd, I, 317-18. Cisimlerin mütemâsilliği görüşünün İslâmî esasların ispat edilmesinde büyük bir ilke olduğunu belirten Râzî de ancak bu yolla Fâil-i Muhtâr olan bir ilâhın varlığına istidlâlde bulunulması ve peygamberlerin mucizeleri, haşir, neşir ve kıyametin isbâtının mümkün olabileceğini söyler. İlâhiyyât, nübüvvât ve meâde dair konuların ispat edilmesinde dayanılan bir ilke olduğundan dolayı cisimlerin mütemâsilliği oldukça önemlidir. Râzî, Metâlib, VI, 189-90.

79 Teftâzânî, Şerhu'l-Makâsıd, I, 311-2, 318, 328, 337; II, 69, 193; Teftâzânî, Şerhu'l-Akâid, 91; Teftâzânî, Tehzîb, 60.

80 Teftâzânî, Şerhu'l-Makâsıd, II, 193. 
gibi ay-üstündeki cisimler de bu iki arazı kabul edebilir. Böylece ayın yarılması mucizesinin aklen mümkünlügü ispat edilmiş olunur. Sonuç olarak Kâdir-i Muhtâr olan Allah'ın, âlemdeki herhangi bir cisimdeki atomları değiştirmeksizin onlara yerleşen arazları değiştirmek suretiyle farklı türdeki cisimleri meydana getirmesinin aklen imkânı cisimlerin benzeşikliği teorisiyle sağlanmaktadır.

(ii) Benzeşik Atomlardan Oluşmuş Farklılaşmış Cisimler: Atomculuğu benimseyen kelâmcılardan bir kısmı tarafından kabul edilen bu yaklaşıma göre, atomlar aynı hakikatlere sahip olduğundan benzeşik olmakla birlikte onlardan oluşan cisimler, benzeşik değil aksine hakikat bakımından farklılaşmış (mütehâlif) cevherlerdir. Aynı hakikate sahip atomlardan meydana gelen cisimlerin hakikat bakımından farklılaşmalarının yolu arazları da hakikate dâhil etmektir. Böylece cisimlerin hakikatini benzeşik atomlarla farklılaşmış arazlar meydana getireceğinden doğal olarak cisimlerin hakikatleri de birbirlerinden farklılaşmış olacaktır. ${ }^{81}$ Bu bağlamda cisimsel türün hakikatinin bir parçası olan araz, bileşikle değil onun diğer bir parçası olan cevherle kaim olmaktadır. Dolayısıyla söz konusu araz, bileşiğe nispetle zâtî iken, bileşiğin diğer parçası olan atomlara nispetle de ârızîdir. ${ }^{82} \mathrm{Bu}$ atomcu yaklaşımı benimseyen kelâmcilar, arazın türün hakikatine dâhil olmasının mümkünlügünü ortaya koymak için "parçaya nisbetle parça-bileşiğe nisbetle parça ayrımına” başvurarak arazın iliştiği nesnenin parçası olması sorununu çözmeye çalışmışlardır. ${ }^{83}$

Bu atomcu anlayışı benimseyen kelâmcıların insanî nefsin hakikatini ifade etmek için söyledikleri "farklı hakikate sahip latif cisim görüşü” şöyle açıklanabilir: İnsanın hakikatini meydana getiren latif cisim, birincil niteliği olan hayat arazından dolayı zâtı gereği canlıdır ve bu cismin hakikati atom cevherleriyle hayat arazından oluşmuştur. Diğer bir ifadeyle hayat arazı, insanî nefsin birincil niteliği olarak hakikatinin bir parçası olduğundan onun hakikat bakımından diğer cisimlerden farklılaşmasını sağlamaktadır. Söz gelimi hayvanî ve bitkisel nefisteki hayat arazı bu cisimlerin hakikatine dâhil değildir. O yüzden insanî nefis zâtı gereği hayat sahibi iken diğer nefislerin hayat sahibi olmaları ârızîdir.

(iii) Farklılaşmış Atomlardan Oluşmuş Farklılaşmış Cisimler: Önceki iki atomcu anlayıştan farklı olarak bunda atomların hakikat bakımından aynılığı kabul edilmemektedir. Atomlar farklı hakikatlere sahip olduğundan onlardan meydana

81 Teftâzânî, Şerhu'l-Makâsıd, I, 312, 318.

82 Teftâzânî, Şerhu'l-Makâsıd, I, 312, 317; Seyyid Şerif Cürcânî, Hâşiyetü alâ Şerhi Muhtasari'l-müntehâ'l-usûlî, nşr. Muhammed Hasan İsmail (Beyrut: Dâru'l-Kütübi'l-i̇lmiyye, 2004), I, 243.

83 İskender Afrodisî de bu ayrımı suretin cevherliği konusunda karşılaşılan problemleri çözmek için kullanmıştır. Bk. İbrahim Halil Üçer, İbn Sînâ Felsefesinde Suret, Cevher ve Varlık (İstanbul: Klasik Yayınları, 2017), 140-2. 
gelen cisimlerin de farklı hakikatlere sahip olması gerekmektedir. Atomların farklı şekillere sahip olduğunu ve bu şekillerin atomların zâtî, yani birincil nitelikleri olduğunu savunanlar, onları farklı hakikatlere sahip cevherler olarak görmüşlerdir. Teftâzânîye göre bu görüş sahipleri, cisimler arasındaki farklılıkları, arazlara değil şekillere dayandırmışlardır. ${ }^{84}$ Îcînnin bazı ibareleri onun bu görüşü benimsediğini gösterirken ${ }^{85}$ bazı ifadeleri de birinci görüşü savunduğuna işaret etmektedir. ${ }^{86}$

Benzeşik atomlardan oluşmuş benzeşik cisimler görüşünü kesin olarak benimsediği anlaşılan Teftâzânînnin "farklı hakikate sahip latif cisim görüşü"nü kabul etmesi beklenemez. Bu nefis görüşü, son iki atomcu anlayışla (yani benzeşik atomlardan oluşmuş farklılaşmış cisimler ve farklılaşmış atomlardan oluşmuş farklılaşmış cisimler anlayışlarıyla) uyumlu bir nefis teorisidir. Zira bu iki atomcu görüşte de cisimlerin farklı hakikatlere sahip oldukları düşünülmektedir. Şu hâlde benimsediği atomcu anlayıştan dolayı Teftâzânînnin “aynı hakikate sahip latif cisim” şeklindeki insanî nefis görüşünü kabul ettiği söylemek daha makul olacaktır.

\subsection{Epistemoloji}

Psikoloji ile epistemoloji arasında çok güçlü bir ilişki bulunmaktadır. Sistematik bir düşünceye sahip bir düşünürün nefsin hakikati konusundaki görüşlerinin bilgi anlayışıyla tutarlı olması beklenir. Bilgi ile nefis teorisi arasındaki bu güçlü bağdan dolayı nefis teorisini inceledikleri eserlerde düşünürler, bilgi anlayışlarının ana çerçevesini de ortaya koymuşlardır. ${ }^{87}$

Kelâmî ve felsefî eserlerde nefsin soyut bir cevher olduğunu savunan İslâm âlimlerinin, görüşlerini temellendirmek için başvurdukları delillerin büyük çoğunluğu bilgi anlayışına dayanmaktadır. Bu bağlamda zikredilen deliller incelendiğinde onların "bilginin suretin husulü olarak kabul edilmesi halinde cismânî varlık yapısına sahip nefiste tümellerin, basitlerin ve zıtların suretlerinin meydana gelmesinin imkânsız olacağı" gibi öncüllerden hareketle ortaya konulduğu görülmektedir. ${ }^{88}$ Teftâzânînnin

Teftâzânî, Şerhu'l-Makâsıd, I, 311-12. Yunan atomculuğunda atomların birincil ve ikincil nitelikleri için bk. Mehmet Bulğen, Kelâm Atomculuğu ve Modern Kozmoloji (Ankara: TDV Yayınlar1, 2015), 94-5.

85 Îcî, Mevâkıf, 186.

86 Îcî, Mevâkıf, 244, 252, 266.

87 Ömer Mahir Alper, Aklın Hazzı: İbn Kemmûne’de Bilgi Teorisi (İstanbul: Ayışığı Kitapları, 2004), 37; İbn Sînâ, Kitâbü'n-Nefs, 32-227; Aristoteles, Ruh Üzerine, çev. Zeki Özcan (İstanbul: Alfa Yayınları, 2000), 63-211.

88 İbn Sînâ'nın nefsin gayri maddî bir cevher olduğuna ilişkin delillerini inceleyen Durusoy, bunların temelinin insanın ictimâî bir varlık olması ve daha çok aklî idrak ile hissî idrak arasındaki farkın açıklanarak aklî idrakin ancak soyut bir cevherde gerçekleşebileceği düşüncesine dayandığını ifade etmektedir. Bk. Durusoy, İbn Sina Felsefesinde İnsan ve Âlemdeki Yeri, 67-77. 
de nefsin soyut bir cevher olduğunu savunanlara nispet ettiği delillerin ekseriyeti bilgi teorisiyle doğrudan ilişkili delillerdir. ${ }^{89}$

Soyut nefis görüşünün dayandığı en güçlü delillerin hareket noktasının İbn Sînâcı bilgi anlayışındaki "suretin husul bulması" olduğunun farkında olan Teftâzânî, cismânî nefis anlayışıyla uyumlu olacak şekilde İbn Sînâcı idrak anlayışını yeniden yorumlayarak düşünce sistemine alır. Her ne kadar bilgi edinme sürecinde nefiste suretin meydana geldiğini kabul etse de Teftâzânî̀ye göre, bu surete sahip nefsin soyut olması zorunlu değildir. Aksine suret, gayri cismânî nefiste husul bulduğu gibi cismânî nefiste de meydana gelebilir. ${ }^{90}$ Teftâzânîye göre, bilgide suretin husulünün reddedilip onun bir izâfetten ibaret olduğu kabul edilmesi halinde de soyut nefis taraftarlarının cismânî nefis anlayışına yönelik eleştirileri ortadan kalkmaktadır. ${ }^{91}$ Nitekim Râzî ve Mu'tezile kelâmcıları izâfet görüşünü kabul etmek suretiyle bu eleştirilerden kaçınmışlardır. Ancak Teftâzânî, düşünce sisteminde başka sorunlara yol açacağını düşündüğünden dolayı bilginin meydana gelmesi için izâfeti yeterli görmemiş, suretin de husul bulması gerektiğini savunmuştur.

\subsection{Ontoloji}

İnsanın hakikatinin latif bir cisim veya aslî parçalar olduğu görüşleri kabul edildiğinde karşı karşıya kalınan en önemli sorunlardan birisi bilen, canlı ve kâdir gibi niteliklerle nitelenenin veya mükellefin kim olduğudur. Bu sorun şöyle detaylandırılabilir: Atomcu fizik anlayışına sahip bir kelâmcı insanî nefsin cismânî olduğunu ifade eden yaklaşımlardan hangisini benimserse benimsesin nihayetinde bu cismin atomlardan meydana geldiğini kabul etmek zorunda kalacaktır. Arazlar birden fazla mahalle kaim olmadığından bilgi, idrak, kudret ve hayat gibi arazlar da insanî nefis olarak kabul edilen cismin tamamıyla değil, ondaki belli atomlarla kaim olacaktır. Şu hâlde insan bedeninin tamamı mı yoksa sadece arazların kendisiyle kaim olduğu parçaları mı bilen, canlı, güç yetiren ve mükellef olmakla nitelenecektir? Nasıl oluyor da insanın belirli bir organına (yani kalb), hatta bu organdaki bir ya da birkaç atoma yerleşen ilim arazından dolayı bir bütün olarak insan "bilen" diye isimlendirilebiliyor? Yine hayat, kudret ve sem' gibi sıfatlar da belirli atomlara münhasır iken nasıl oluyor da atomların tamamından oluşan insanın canlı, bilen, gören ve fail olduğu söylenebiliyor? ${ }^{92}$ Eğer insanın hakikati bu arazların yerleştiği atomlardan ibaret değil de başka

92 Richard M. Frank, "Ebû Hâşim'in Ahvâl Teorisi: Yapısı ve İşlevi”, çev. Hayrettin N. Güdekli, Marmara 
atomların da dâhil olduğu bir bütün ise bu durumda örneğin ilim arazı sadece yerleştiği atomların hakiki anlamda bilen olmakla nitelenmesini sağlayacaktır. Dolayısıyla bir bütün olarak insan nefsine âlim denilmesi mecazi anlamda olacaktır. Zira ilim arazı, insanın nefsinde bulunan atomlardan bir kısmına yerleşmişken diğerlerine yerleşmemiştir.

İnsanın bu bünyeden ibaret olduğunu yani çok sayıda atomdan meydana gelmiş bileşik bir varlık olduğunu savunan Ebû Hâşim el-Cübbâî, ortaya koyduğu haller teorisi sayesinde bu sorunu çözüme kavuşturmaya çalışmıştır. ${ }^{93}$ Ona göre, her ne kadar bilgi arazı sadece kalpte bulunan atomlara yerleşse de bir bütün olarak bileşiğin tamamına ait olan bir halin (sıfatın) sebebidir. Diğer bir ifadeyle kalpte bulunan bilgi arazı sadece bulunduğu mahalli nitelemesine rağmen onun sebep olduğu âlimiyyet hali bütün olması bakımından insana bilen denilmesini mümkün kılmaktadır. Bu tür hallerden dolayı bütün olması bakımından insan, mecazi değil, gerçek anlamda bilen olmakla nitelenir. ${ }^{94}$ Halleri kabul eden Cüveynî de bu sorunun çözümünde haller teorisine dikkat çekmektedir. Ona göre, Eşârîlerden halleri inkâr edenlerin atomlardan meydana geldiğini düşündükleri insanı bir bütün olarak ve hakiki anlamda "âlim" ismiyle isimlendirdiklerini temellendirmeleri mümkün değildir. Arazların aksine bütünle kaim olup onu niteleyebilme işlevlerinden dolayı haller teorisi, insan hakkında gerçek anlamda "âlim" ismini kullanma imkânı sağlamaktadır. ${ }^{95}$

Kalânisî (ö. IV/X. yüzyıl başları [?]) ve Ebü'l-Kâsım el-Ensârî en-Nîsâbûrî (ö. 512/1118) gibi klasik Eş'arî görüşü devam ettiren düşünürler ise halleri kabul etmediklerinden arazların sadece belirli atomlara yerleştiklerini ve yalnızca yerleştikleri atomların gerçek anlamda canlı ve bilen olarak nitelenebileceğini iddia etmişlerdir. Böylece insanın hakikati olarak gördükleri duyulur bedenin tamamının mecazi anlamda bu sifatlarla nitelendiğini savunmuşlardır. ${ }^{96}$

Bu çalışmada, Teftâzânînin insanî nefsin hakikatinin bedene sirayet eden ve hakikat bakımından diğer cisimlerle benzeşik latif cisim olduğunu kabul ettiği iddia

Üniversitesi İlahiyat Fakültesi Dergisi 46 (2014): 228-9; Ayman Shihadeh, “Classical Ash'arī Anthropology: Body, Life and Spirit", The Muslim World 102/3-4 (Ekim 2012): 462.

93 Frank, "Ebû Hâşim'in Ahvâl Teorisi", 228-29.

94 Frank, "Ebû Hâşim'in Ahvâl Teorisi", 229, 233-4; Richard M. Frank, Beings and Their Attributes: The Teaching of the Basrian School of the Mu'tazila in the Classical Period, Studies in Islamic Philosophy and Science (Albany: State University of New York Press, 1978), 38-53; Shihadeh, "Classical Ash'arī Anthropology", 433-77.

95 Cüveynî, eş-Şâmil, 665-66; Shihadeh, "Classical Ash'arī Anthropology", 455-56.

96 Shihadeh, "Classical Ash'arī Anthropology”, 451-6; Ebü'l-Kâsım Selmân b. Nâsır b. İmrân b. Muhammed en-Nîsâbûrî el-Ensârî, el-Gunye fi'l-kelâm, thk. Mustafa Haseneyn Abdülhâdî. (Kahire: Dâru's-Selâm, 2010), II, 956-62. 
edilmektedir. Eğer bu iddia doğru ise yukarıda zikredilen ontolojik soruna ilişkin Teftâzânî̀nin bir çözümünün olması gerekmektedir. Evet o, mütekaddimîn kelâmının bazı öğretilerinde değişikler yapmak suretiyle sorunu çözmeye çalışmaktadır. Öncelikle Teftâzânîye göre, nefis latif bir cisim olarak kabul edildiğinde bir bütün olarak bilen ve canlı olmakla nitelenen beden değil, ona sirayet etmiş latif cisimdir. İdraklerin tamamı ve diğer nefsânî sıfatlar latif cisme yerleşmişlerdir. Bu latif cisme yerleşen arazlar ise bütün olması bakımından nefse yerleşebilirler. Bu anlamda ona göre bilginin mahalli kalptir, ancak bu kalple kastedilen duyulur olan ve cerrahî operasyon esnasında görülen ve hayvanlarda da bulunan organ değildir. Aksine kalp ile kastedilen insanın kendisiyle diğer varlıklardan ayrıştığı insan ruhudur. ${ }^{97}$ Şu hâlde bilgi arazı, (i) ya bir bütün olarak latif cismin tamamına, (ii) ya onun ayrı ayrı her bir atomuna (iii) ya da ondaki sadece bazı atomlara yerleşmiştir. Üçüncü ihtimal yani bilginin sadece bazı atomlara yerleştiği kabul edildiğinde nefsin mecazi anlamda bilen olmakla nitelenmesi gerekeceği ifade edilmişti. İkinci ihtimalde varsayıldığı üzere bilginin insanî nefsin her bir atomuna ayrı ayrı yerleşmesi halinde ise tek bir bilgi meydana geldiğinde insanî nefsi meydana getiren atomlar sayısı kadar çok bilginin insanda oluşması gerekir ki bunun kabul edilmesi mümkün değildir. Ancak belirtmek gerekir ki halleri reddetmesine rağmen Teftâzânî’nin düşünce sistemi açısından birinci ihtimalin kabul edilmesinin önünde herhangi bir engel yoktur. Zira Teftâzânî, mütekaddimîn kelâmcıları tarafından kabul edilen "bir arazın birden fazla mahalle kaim olamayacağı” ilkesini farklı bir şekilde yorumlamaktadır. Ona göre bu ilkeyle kastedilen şey, tek bir arazın bir mahalle yerleşmişken aynıyla başka bir mahalle yerleşemeyeceğidir. Yoksa bir arazın, birleşme (ictimâ) arazı sayesinde kendisi için tek bir mahalle dönüşen birden fazla atomdan meydana gelmiş toplamla (mecmû), yani cisimle kaim olması kastedilmemiştir. Bu anlamda bir araz, çok şeyden oluşmuş bir bileşiğe bütün olması bakımından yerleşebilir ve onunla kaim olabilir. ${ }^{98}$ Dolayısıyla latif cisim olan insanî nefsin bütününe arazlar ilişmekte ve bu ilişme sayesinde insan gerçek anlamda bilen, canlı ve mükellef olmakla nitelenmektedir.

\subsection{Teoloji}

Uluhiyyât, nübüvvât ve semiyyât gibi teoloji konularında benimsediği görüşler bir kelâmcının düşünce sistemini belirgin hale getiren en önemli unsurlardır. Ontoloji, epistemoloji, fizik vb. konularında kelâmcının ortaya koyduğu yaklaşım, daha çok

98 Teftâzânî, Şerhu'l-Makâsıd, I, 177, 288. 
teoloji konularındaki görüşlerinin etkisinde ve onlarla uyumlu şekilde oluşmaktadır. Zira teoloji konuları, kelâm ilminin temel maksatlarıdır.

Teftâzânî̀nin düşünce sisteminde de teoloji konularının onun insanî nefsin hakikatine yaklaşımını büyük oranda etkilediği görülmektedir. Onun insanî nefsin hakikatine ilişkin olarak ortaya koyduğu çerçeveyi belirginleştirebilmek için özellikle meleklerin mahiyeti ve ölüm ötesi hayata dair görüşlerinin incelenmesi önem arz etmektedir.

\subsubsection{Melek, Cin ve Șeytanın Mahiyeti}

Meleklerin nurânî varlıklar olduğu, konuyla ilgili naslardan dolayı genel kabul görmekle birlikte ruhânî yapıda olmalarının varlık yapıları bakımından ne anlam ifade ettiği düşünürlerin varlık anlayışlarına bağlı olarak değişmektedir. Diğer bir ifadeyle meleklerin varlık yapıları bakımından soyut cevherler veya cismânî varlıklar olduğu konusunda insanî nefsin hakikati meselesinde olduğu gibi farklı görüşler bulunmaktadır. Aslında düşünürlerin meleklerin mahiyetine dair ileri sürdükleri görüşler, genellikle onların varlıkların taksimine dair benimsedikleri yaklaşımları çerçevesinde şekillenmiştir. Söz gelimi varlık taksiminde soyut cevherlere yer veren filozoflar, melekleri, soyut varlık kategorisine dâhil ederken varlıkları kadîm ve hâdis şeklinde iki kısma ayırıp tüm hâdislerin de cismânî olduğunu savunan kelâmcılar ise onları cisimsel latif varlıklar olarak görmüşlerdir. Dolayısıyla bir düşünürün meleklerin varlık yapısına dair görüşleri aynı zamanda onun insanî nefsin mahiyetine ilişkin görüşü hakkında da fikir sahibi olmamızı sağlar.

Filozofların soyut cevherlerden kabul ettikleri akıllar hakkında detaylı bilgiler veren Teftâzânî, onların din dilindeki melekleri düşünce sistemlerindeki soyut akıllar ve göksel nefisler olarak ifade ettiklerini söyler. Dahası cinlerin varlığını kabul eden filozoflar, onların da soyut cevher olduğunu düşünmüşlerdir. Bu anlayışa göre soyut varlıklar olmaları sebebiyle cinler, unsurlardan meydana gelmiş cisimlerde tasarrufta bulunabilir ve onları etkileyebilirler. Diğer taraftan şeytanların varlığını kabul eden filozoflar, onların insan fertlerinde bulunan mütehayyile gücünün kendisi olduğunu söylemişlerdir. Ancak bazı filozoflar ise cinler ve şeytanların ayrı birer tür olmadıklarını, aksine insanî nefislerin, bedenlerinden ayrıldıktan sonraki durumlarına göre aldıkları farklı isimler olduğunu savunmuşlardır. Bedeninden ayrılan ve onunla ilişkisi kesilen insan ruhu, aklî dürtülere tabi olmuş iyi bir ruh ise "cin", eğer kötü ve çirkin şeylere sevk eden kötü bir ruh ise "şeytan" olarak isimlendirilir. Sonuç olarak Teftâzânîye göre, filozofların düşüncesinde her ne kadar şeytanların varlık yapısına ilişkin farklı yaklaşımlar söz konusu olsa da melekler ve 
cinlerin soyut yapıda oldukları onların varlıklarını kabul eden filozoflar tarafından ileri sürülmüştür. ${ }^{99}$

Varlıklara dair taksiminde Allah dışındaki soyut varlıklara yer vermeyen Teftâzânî, bu görüşüyle uyumlu olarak melek, cin ve şeytanların cisimsel varlıklar olduğunu savunmaktadır. Ona göre meleklerin latif cisimler olduğu, ümmetin büyük çoğunluğu tarafından kabul edilen ve kitapla sünnetin zahirinin teyit ettiği bir görüştür. Melekler "nurânî latif cisimler", cinler "hava tabiatlı latif cisimler" ve şeytanlar ise "ateş tabiatlı cisimler"dir. Bu üç tür de dört unsurun imtizacından meydana gelmekle birlikte şeytanda ağır basan unsur ateş iken melek ve cinde ise hava unsuru daha etkindir. Hava ve ateşin son derece şeffaf ve latif olması nedeniyle bunların kendilerinde daha fazla oranda bulunduğu melek, cin ve şeytan çok dar yerlere nüfuz edebiliyorlar ve gözle görülmüyorlar. ${ }^{100}$ Teftâzânî, bunların cismânî yapıda olmaları halinde görülmeleri gerektiği şeklindeki itirazı da isabetli bulmaz. Ona göre, mümkün şeylerin tamamı Kâdir-i Muhtâr olan Allah'a dayanmakta olup O'nun bazı gözlerde ve durumlarda onlara ilişkin görme idrakini yaratması bazılarında da yaratmaması mümkündür. ${ }^{101}$

\subsubsection{Kabir Hayatı}

Teftâzânînin kabir hayatına dair tasavvuru onun bedenin ötesinde bir ruhun varlığını kabul ettiğini ve aslî parçaları insanî ruhun değil, bedenin hakikati olarak kabul ettiğini göstermektedir. Esasen Teftâzânî nefsin hakikatine ilişkin görüşleri açıkladığı nefis bahsinde kelâmcıların itimat edilen iki görüşü (latif cisim ve aslî parçalar) olduğunu ifade etmiş, ancak bunlardan hangisini tercih ettiğini belirtmemiştir. Bu anlamda kabir hayatına dair açıklamaları, aslî parçaları nefsin hakikati olarak kabul etmediğini göstermesi bakımından son derece önemlidir.

Teftâzânîye göre kabirde sorgu-suale, azap ve nimete hem ruh hem de beden muhatap olacaktır. Ancak beden tamamen parçalara bölünmüş ve ruh da bedenden ayrılmış iken bu nasıl olacaktır? Ona göre, tam (kâmil) ve eksik (nâkıs) olmak üzere iki tür hayat vardır. İnsanın bedeni dağılıp parça parça olsa bile onun aslî parçaları bâkî olmaya devam edeceğinden Allah, bu "aslî parçalara" elem ve lezzet alabilecekleri ölçüde bir hayat (eksik hayat) verir. Dolayısıyla bedende sadece lezzet ve elem gibi idraklerin gerçekleşmesi için ruhun bedene dönmesine gerek yoktur. Ancak bu idraklerin yanı sıra kudret ve ihtiyarî fiiller için gerekli olan "tam hayat" ise ruhun 
onda bulunmasına bağlıdır. Bu ise ba's gerçekleştikten sonra olacaktır. ${ }^{102}$ Hayatın bedende yaratılması için bünyenin bulunması şart değildir. Kabirde bedenin bünyesi dağılmış olsa bile Allah'ın sadece aslî parçalarda veya sadece bir atomda bile hayatı yaratması mümkündür. ${ }^{103}$ Ancak bedenin aslî parçalarında hayatın yaratılmasına gerek kalmaksızın onlarda lezzet ve elem gibi idraklerin meydana geldiğini iddia etmek hak ehlinin kabul ettiği asıllara aykırıdır. ${ }^{104}$

İnsan ruhu, her ne kadar bedenden ayrılmış olsa da kabir hayatı esnasında bedeniyle "bir tür" ilişkisi devam etmektedir ve sahih hadis rivayetlerinden anlaşıldığ1 kadarıyla kabrini ziyarete gelenlerin seslerini işitir. Böylece ölümden sonra ruhu ile bedeninin aslî parçaları arasındaki irtibat, tamamen kopmadığından ve aralarında "bir tür" taalluk devam ettiğinden kabir ziyaretleri fayda sağlamakta ve ziyaret esnasında diri ile ölünün ruhları arasında görüşme ve feyiz gerçekleşebilmektedir. ${ }^{105}$

\subsubsection{Haşir}

Teftâzânînnin haşir konusundaki açıklamaları da tıpkı kabir hayatında olduğu gibi onun aslî parçaları nefsin değil, bedenin hakikati olarak gördüğünü ve tenasühe düşmesini engelleyecek bir esas olarak kabul ettiğini göstermektedir. Teftâzânî'nin insanî nefis ile aslî parçaları birbirinden ayrı unsurlar kabul ettiğini gösteren en önemli pasajlardan birisi şudur:

“Dirilme (ba's), Allah’ın, aslî parçalarını toplayıp bu parçalara ruhları döndürmek suretiyle ölüleri kabirlerden diriltmesidir. Deriz ki: Eğer ikinci beden ilk bedenin aslî parçalarından yaratılmamış olsaydı tenâsüh söz konusu olurdu. Şayet böyle bir şey [bedeni ilk bedenin aslî parçalarından yaratma] tenâsüh olarak isimlendirilirse bu sadece isimsel bir tartışma olur. Böyle bir bedene ruhun döndürülmesinin imkânsızlığına dair hiçbir delil yoktur. Aksine tenâsüh olarak isimlendirilsin veya isimlendirilmesin deliller onun gerçekliğini göstermektedir." 106

104 Teftâzânî, Şerhu'l-Makâsıd, II, 221-2.

105 Teftâzânî, Şerhu'l-Makâsıd, II, 43.

106 Teftâzânî, Şerhu'l-Akâid, 68. Bedensel haşrin, bedenin aslî parçalarının dağınık iken tekrar bir araya getirilmesi yoluyla mı olacağı yoksa bedenin parçaları yok edildikten sonra tekrar varlığa çıkarılmak suretiyle mi gerçekleşeceği konusu tartı̧̧malıdır. (i) Dağınık parçaların bir araya getirilmesi yoluyla haşir, (ii) yokluktan varlığa çıkarmak yoluyla haşir ve (iii) bu konuda tevakkuf edilmesi olmak üzere üç farklı yaklaşım bulunmaktadır. Şerhu'l-Akâid'den yapılan bu alıntı, Teftâzânînin birinci görüşü tercih ettiğini gösterse de daha sonra telif ettiği Şerhu'l-Makâsıd eserinde her iki görüşe de işaret eden ayetlerin bulunduğunu belirttikten sonra doğrusunun bu konuda tevakkuf etmek olduğunu söyleyerek üçüncü görüşü benimser. Bk. Teftâzânî, Şerhu'l-Makâsıd, II, 215-6. 
Bu pasajda görüldüğü gibi yeniden dirilişte insan ruhunun toplanılan aslî parçalara döndürüleceği ifade edilmektedir. Dolayısıyla ruh ve aslî parçalar ölümden sonra yeniden diriliş gerçekleşinceye kadar birbirlerinden ayrılmış olarak bulunuyorlar. Şerhu'l-Makâsıd'da meâde dair açıklamaları da bu pasajda yer alan görüşlerini teyit etmektedir. ${ }^{107} \mathrm{Bu}$ anlamda birincisi, ceza ve mükâfatın asıl muhatabı olan ve sürekliliği muhafaza edilmiş bir öznenin bulunması gerekir. İdrakler bu özneye, yani insanî ruha ait olduğundan sevap ve mükâfatı hak eden de odur. Latif bir cisim olan bu ruh devamlıdır. İkincisi, bedensel haşre temel oluşturan, bir ferdin bedenini ona özgü kılan ve dünya hayatında ömrünün başından sonuna kadar bedeninde bulunan bazı parçaların daha olması gerekir. Yeniden dirilişte insanî ruhun kendisine döndürüleceği parçalar, bu aslî parçalardan oluşan bedendir. Zira eğer öyle olmasa öldükten sonra ruhun kendisine döndürüldüğü bedenin bu dünyadaki beden olduğunu söylememizi mümkün kılacak bir ortak parçadan bahsedilemeyecektir. Diğer bir ifadeyle böyle bir ortak unsurun bulunduğunu reddetmek, bir anlamda tenâsühü kabul etmektir. ${ }^{108}$ Dünya hayatında insanın bedeninde ömrü boyunca sürekli değişen fazla parçaların aynısının değil benzerlerinin yeniden diriliş esnasında insan bedeninin parçası olmalarında bir mahsur yoktur.

Ceza ve mükâfata muhatap olacak öznenin insanî nefis olduğunu savunan Teftâzânînin düşüncesinde ceza ve mükâfatın gerçekleşmesi için bedensel haşrin gerektiğini söyleyerek ona aklî bir argüman getirmek mümkün değildir. Zira insanın hakikati yalnızca ruhtur ve ceza-mükâfatın gerçekleşmesi için onun varlığı yeterlidir. Ancak bedensel haşri ispatlayan bir aklî delilin bulunmadığını savunması Teftâzânînin bedensel haşri inkâr ettiği anlamına asla gelmez. Çünkü ona göre bedensel haşrin delili akıl değil nakildir. Biz aklî delillerden hareketle değil, delâleti ve sübutu kati olan çok sayıdaki nas dolayısıyla bedensel haşri kabul ediyor ve ona iman ediyoruz. Eğer naslarda açık bir şekilde ifade edilmeseydi sırf ceza ve mükâfatın gerekliliğinden hareketle bedensel haşrin gerçekleşeceği temellendirilemezdi.

Teftâzânî, bedensel haşrin delilinin akıl değil, kati naslar olduğunu söylerken esasında Mu'tezile'nin yaklaşımını eleştirmektedir. Zira Mu'tezile, iyi ve kötü eylemleri işleyen bu bedenin haşredilmesinin aklî bir zorunluluk olduğunu iddia etmiştir. Onlara göre, itaat ve isyan eden bütün olarak insan veya aslî parçalardır. Teftâzânîye göre, eğer mükâfat ve cezayı hak edenle gerçek özne kastediliyorsa bu insanın ruhudur. Eğer zâhirî özne kastediliyorsa o zaman insanın ömrünün başından sonuna kadar bütün parçalarının ahirette hasredilmesinin gerektiğini savunmak gerekir. Çünkü insanın 
idrak ve fiilleri ruha değil de bedene aitse ceza ve mükâfatın bedenin organlarının benzerine değil aynısına yönelik olması gerekecektir. Bir yamyam tarafından yenilen insanın parçaları hem kendi parçası hem de yamyamın parçası olmaktadır. Bu durumda onların kimin bedeninde haşrolacağı ve o parçalarla biri iyilik, diğeri de kötülük yaptığında hem mükâfat hem cezayı nasıl göreceği sorunu ortaya çıkmaktadır. Ayrıca gençliğinde herhangi bir suç işleyen kimsenin, yaşlandığında o suçu işlediği tespit edilmesi halinde cezalandırılmaması gerekir. Çünkü kendisiyle o suçun işlendiği beden azaları yaşlılıkta neredeyse tamamen değişmiştir. Mu'tezile'nin yaklaşımını mezkûr sorunları dile getirerek reddeden Teftâzânî̀ye göre, ceza ve mükâfatın dayanağı ve sebebi olan irade, fiil, idrak ve hareketlerin tamamının ilkesi beden veyahut hem beden hem ruh değil sadece ruhtur. Bundan dolayı da ceza ve mükâfatı hak eden insanın ruhudur. ${ }^{109}$

\section{Sonuç}

İslâm düşüncesinde önemli tartışma konularından biri olan insanın hakikati meselesine dair çok farklı yaklaşımlar söz konusu olmakla birlikte bunlar, en genel hatlarıyla cismânî nefis ve soyut nefis olmak üzere iki kısımda incelenmiştir. Müteahhirîn dönem kelâmcıları genelde insanî nefis konusundaki görüşlerini açık ve net bir şekilde belirtmeseler de diğer konulardaki görüşlerinden hareketle bu hususta bir sonuca ulaşmak mümkündür. Müteahhir dönem düşünürlerinden biri olan Teftâzânî'nin de epistemoloji, fizik, ontoloji ve teoloji konularındaki görüşleri bir bütün olarak tahlil edildiğinde insanî nefsin hakikati ve insan tasavvuru konusundaki görüşleri de belirginleşmektedir. Duyumsanan bedenin ötesinde bulunan bir nefsin varlığının bedîhî olduğunu savunan Teftâzânî, tevarüs ettiği geleneği de bu anlayışı çerçevesinde yorumlamıştır. İnsanî nefsin bedenin ötesinde bulunmasının apaçık olduğunu söyleyerek katı monist bir insan anlayışından uzaklaşıp soyut cevher anlayışına yaklaşmıştır. Bununla birlikte onun, soyut cevher anlayışını da benimsemediği anlaşılmaktadır. Bedenin ötesinde bulunan insanî nefsin cismânî veya soyut bir cevher olduğuna dair kesin bir aklî veya naklî delil bulunmadığını söylese de fizik anlayışıyla en tutarlı olan, diğer cisimlerle aynı hakikate sahip latif cisim görüşüdür.

Teftâzânî'nin düşünce sistemi çerçevesinde ortaya çıkan insan tasavvuruna göre, insanın duyulur bedeni ve bedenin ötesinde bulunun bir ruhu vardır. İnsanî nefis olarak isimlendirilen ruhu, insanın hakikati ve özüdür. Diğer cisimlerle aynı hakikate sahip bir latif cisim olan insanî nefis, atomlardan meydana gelmiş olup kendisine arazlar ilişmektedir. Hayat, bilgi, kudret ve irade gibi nefsânî keyfiyetlerin tamamı bu latif 
cisme ilişmiş arazlar, dolayısıyla da nefsin sıfatlarıdır. Bu arazların mahalli bütün olması bakımından nefsin kendisi olduğundan insanî nefis mecazen değil, gerçek anlamda canlı, bilen ve kâdir olmakla nitelenir. Bir cismi meydana getiren atomlar tam bir bitişiklikle birleşmeyip aralarında boşluklar bulunduğundan nefsin bedenin atomları arasındaki boşluklara yerleşmek suretiyle ona sirayet etmesi mümkün olmaktadır.

Duyulur beden kesif bir cisim olup cevher ve arazlardan meydana gelmiştir. $\mathrm{Bu}$ duyulur bedenin de birincisi, doğduğu günden ölümüne kadar sürekli olarak onda bulunan ve bedenin özünü oluşturan aslî parçaları; ikincisi ise hayatının belli bir diliminde onda bulunan fazlalık parçaları vardır. Latif cisim olan insanî nefis ile kesif cisim olan bedeni arasındaki irtibat hayvanî ruh denilen ve kalpte oluşup bütün bedene yayılan diğer bir latif cisim vasıtasıyla sağlanmaktadır.

Nefsin bedenden ayrılmasıyla ölüm gerçekleşir ve nefis ruhlar âlemine geçerken bedende bulunan hayvanî ruh ve fazlalık parçalar da yavaş yavaş dağılır. İnsanî nefse yerleşmiş olan hayat ve idrakler gibi arazlar onun bedeni terk etmesinden sonra da onunla birlikte bulunur. Hatta bedeni terk ettikten sonra insanî nefis hem tümelleri hem tikelleri idrak etmeye devam eder. Bu bağlamda bedenden ayrı bulunan ruhun, bedeniyle ve bedeninin konulduğu kabirle bir tür taalluku bulunduğundan kendisini ziyaret edenlerin seslerini işitir. İnsanın bedeni dağlıp parça parça olsa bile onun aslî parçaları bâkî olmaya devam ettiğinden bu "aslî parçalara" elem ve lezzet alabilecekleri ölçüde bir hayat (eksik hayat) Allah tarafından verilir. Böylece bedenin kabirde azap ve lezzeti tatması mümkün olur. Dolayısıyla her ne kadar kabirde ruh, bedenden ayrı olsa da Allah'in aslî parçalara verdiği bu eksik hayat sayesinde kişinin bedeni azap çekmekte ve lezzet alabilmektedirler. Diğer taraftan beden dağılip parçalanmasına rağmen insanî nefis ilim, kudret, hayat ve idrak gibi nefsânî niteliklerle nitelenmeye devam etmektedir. Dolayısıyla ölümden sonra bu cismânî ruhun azap ve elem çekmesinde herhangi bir sorun bulunmamaktadır. Haşirde bedenin aslî parçaları bir araya getirilip insanî nefis kendisine döndürülecek ve ahiret hayatında ruh ile beden bir arada olacaktır. Dünyadaki beden ile ahiretteki beden fazlalık parçaları bakımından benzer, aslî parçalar itibariyle aynıdırlar. Ruhun kendisine döndürüldügü beden ile dünyadaki beden aslî parçalar itibariyle aynı olduğundan meâd, tenâsühten farklı bir olgu olarak karşımıza çıkmaktadır.

\section{Kaynakça}

Akçay, Mustafa. “Gazzâli’de Ruh Tasavvuru”. Dini Araştırmalar 7/21 (2005): 87-116.

Alper, Ömer Mahir. Aklın Hazzı: İbn Kemmûne’de Bilgi Teorisi. İstanbul: Ayışığı Kitapları, 2004.

Altaş, Eşref. “Fahreddîn er-Râzî̀ye Göre İnsanın Mahiyeti ve Hakikati -Mücerred Nefs Görüşünün Eleştirisi-”. İnsan Nedir?: İslâm Düşüncesinde İnsan Tasavvurları, 139-99. Ankara: İLEM Yayınları, 2019. 
Âmidî, Ebü'l-Hasan Seyfüddin Ali b. Muhammed. Ebkârü'l-efkâr fî usûli'd-dîn. 5 c. Kahire: Dâru'l-Kütüb ve'l-Vesâiki'l-Kavmiyye, 2004.

Aristoteles. Ruh Üzerine. Çeviren Zeki Özcan. İstanbul: Alfa Yayınları, 2000.

Arkan, Atilla. "Psikoloji: Nefis ve Akıl”. İslâm Felsefesi: Tarih ve Problemler, ed. M. Cüneyt Kaya. İstanbul: İSAM Yayınları, 2013.

Attar, Muhammad Fariduddin. "Fahr al-Din al-Razi on the human soul: a study of the psychology section of al-Mabahith al-masriqiyya fi'ilm al-ilhahiyyat wa-l-tabi'iyyat”. Yüksek Lisans Tezi, McGill University Institute of Islamic Studies, 2014.

Beyzâvî, Kâdî Nâsırüddin Ebû Saîd Abdullah b. Ömer. Misbâhü'l-ervâh fî usûli'd-dîn, thk. Saîd Fûde. Ammân: Dâru'r-Râzî, 2007.

——_ Tavâli u'l-envâr, thk. Süleyman Abbas. Beyrut ve Kahire: Dâru'l-Cîl ve el-Mektebetü'l-Ezheriyye li'ttürâs, 1991.

Biçer, Ramazan. “Şemseddin Semerkandîye Göre İnsan Psikolojisinin Temel Nitelikleri”. Al Farabi IV. Uluslararası Sosyal Bilimler Kongresi Kongre Tam Metin Kitabı, ed. Özlem Ülger ve Atabek Movlyanov, 852-62. İksad Yayınevi, 2019.

Bulğen, Mehmet. Kelâm Atomculuğu ve Modern Kozmoloji. Ankara: TDV Yayınları, 2015.

Cengiz, Yunus. “Mu'tezile'nin İnsan Düşüncesinde Rakip İki Tasavvur: Ebü’l-Hüzeyl ve Nazzâm Gelenekleri”. Nazariyat İslâm Felsefe ve Bilim Tarihi Araştırmaları Dergisi 4/2 (Nisan 2018): 55-72.

Cürcânî, Seyyid Şerif. Hâşiyetü alâ Şerhi Muhtasari'l-müntehâ'l-usûlî, nşr. Muhammed Hasan İsmail. 3 c. Beyrut: Dâru'l-Kütübi'l-İlmiyye, 2004.

_—_- Şerhu'l-Mevâkıf : Mevâkıf şerhi (metin-çeviri), çev. Ömer Türker. 3 c. İstanbul: Türkiye Yazma Eserler Kurumu Başkanlığı Yayınları, 2015.

Cüveynî, İmâmü'l-Haremeyn Ebü'l-Meâlî Rüknüddîn Abdülmelik b. Abdillâh el-. el-İrşâd ila kavâtii'l-edilleti fî usûli'l-i'tikad, thk. Muhammed Yusuf Mûsâ. Kahire: Mektebetü'l-Hancî, 1950.

——_- eş-Şâmil fî usûli'd-dîn, nşr. Ali Sâmî en-Neşşâr vd. İskenderiye: Münşeetü'l-Maârif, 1969.

Durusoy, Ali. İbn Sînâ Felsefesinde İnsan ve Alemdeki Yeri: (Nefs, Akıl ve Ruh). İstanbul: Marmara Üniversitesi İlahiyat Fakültesi Vakfı Yayınları, 2012.

Ensârî, Ebü'l-Kâsım Selmân b. Nâsır b. İmrân b. Muhammed en-Nîsâbûrî, el-Gunye fi'l-kelâm, thk. Mustafa Haseneyn Abdülhâdî. 2 c. Kahire: Dâru's-Selâm, 2010.

Erdinç, Ziya. “Klasik Sonrası İslâm Düşüncesinde İnsanın Hakikatine İlişkin Önemli Bir Sorun: Soyut Nefis Tikelleri Bilebilir Mi?". İnsanın, İnancın ve Mekanın İnşası-II: Değer ve Kavramlar Uluslararası ve Disiplinlerarası Ruh Sempozyumu Bildirileri ve Özetler Kitabı. Çanakkale: ÇOMÜ Yayınları, 2021.

_—_ “ “Teftâzânîdde Bilen Bir Özne Olarak İnsan”. İnsan Nedir? İslâm Düşüncesinde İnsan Tasavvurları, ed. Ömer Türker ve İbrahim Halil Üçer, 243-92. Ankara: İLEM Yayınları, 2019.

____. “Teftâzânî̀de Bilgi Teorisi”. Doktora Tezi, Sakarya Üniversitesi Sosyal Bilimler Enstitüsü, 2019.

Eş‘ârî, Ebü’l-Hasan. Makâlâtü'l-İslâmiyyîn: İlk Dönem İslâm Mezhepleri, haz. Ömer Aydın ve Mehmet Dalkılıç. İstanbul: Türkiye Yazma Eserler Kurumu Başkanlığı Yayınları, 2019.

Frank, Richard M. Beings and Their Attributes: The Teaching of the Basrian School of the Mu'tazila in the Classical Period. Studies in Islamic Philosophy and Science. Albany: State University of New York Press, 1978. 
———. "Ebû Hâşim'in Ahvâl Teorisi: Yapısı ve İşlevi”. Çeviren Hayrettin N. Güdekli. Marmara Üniversitesi İlahiyat Fakültesi Dergisi 46 (2014): 225-36.

Gazzâlî, Ebû Hâmid Muhammed. İhyâu ulûmi'd-dîn. 4 c. Beyrut: Dâru'l-Marife, 2004.

___. Me'âricü'l-kuds fì medârici márifeti'n-nefs. Beyrut: Dâru'l-Âfâki'l-Cedîde, 1975.

Heemskerk, Margaretha T. " ‘Abd al-Jabbār al-Hamadhānī on Body, Soul and Resurrection”. A Common Rationality: Mu ' tazilism in Islam and Judaism, ed. Camilla Adang, Sabine Schmidtke ve David Sklare, 127-56. Würzburg: Ergon Verlag in Kommission, 2007.

İbn Fûrek, Ebû Bekr Muhammed b Hasan el-Ensârî. Mücerredü makâlâti'ş-şeyh Ebi'l-Hasan el-Eş'ari, thk. Daniel Gimaret. Beyrut: Dâru'l-Meşrik, 1987.

İbn Kayyim el-Cevziyye, Ebû Abdullah Şemseddin Muhammed. Kitâbü'r-Rûh, thk. Muhammed Ecmel Eyyûb el-Islâhî. 2 c. Mekke: Dâru'l-Âlemi'l-Fevâid, 1432.

İbn Sînâ, Ebû Alî Hüseyn b. Abdillâh b. Alî. Kitâbu'ş-Şifâ: Kitâbü’n-Nefs, ed. Fazlurrahman. Londra: University of Durham, 1959.

_—_Metafizik, çev. Ekrem Demirli ve Ömer Türker. 2. bs. 2 c. İstanbul: Litera Yayıncılık, 2013.

İbnü'l-Melâhimî, Rüknüddin İbnü'l-Melâhimî el-Hârizmî. Kitâbü'l-fâik fí usûli'd-dîn, thk. Wilfred Madelung ve Martin McDermott. Tahran: Iranian Institute of Philosophy-Institute of Islamic Studies Free University of Berlin, 2007.

- - Tuhfetü'l-mütekellimîn fi'r-red 'ale'l-felâsife, thk. Hassan Ansari ve Wilfred Madelung. Tahran: Iranian Institute of Philosophy-Institute of Islamic Studies Free University of Berlin, 2008.

Îcî, Adudüddin. el-Mevâkıf fí ilmi'l-kelâm. Beyrut: Âlemü'l-Kütüb, t.y.

İsfahânî, Mahmûd b. Abdurrahman Şemsüddin. Tesdîdü'l-kavâid fi şerhi Tecrîdü'l-akâid, nşr. Hâlid b. Hammâd el-Advânî. 2 c. Beyrut: Dâru'l-Ziyâ', 2012.

Ka'bî, Ebü'l-Kâsım el-Belhî, Kitâbu'l-Makâlât ve meahû Uyûnu'l-Mesâil ve'l-Cevâbât, thk. Hüseyin Hansu, Râcih Kürdî ve Abdülhamîd Kürdî. İstanbul-Amman: Kuramer-Dâru'l-Feth, 2018.

Kâdî Abdülcebbâr, Ebü'l-Hasen. el-Mugnî fí ebvâbi't-tevhîd ve'l-adl: et-Teklîf, nşr. Muhammed Ali en-Neccâr ve Abdülhalîm en-Neccâr. C. 11. 20 c. Kahire: ed-Dâru'l-Mısriyye, 1965.

_—_. Şerhu'l-Usûli'l-hamse, nşr. Abdülkerim Osman. Kahire: Mektebetü Vehbe, 1988.

Kaş, Murat. "Seyyid Şerîf Cürcânî̉de Zihnî Varlık". Doktora Tezi, Marmara Üniversitesi Sosyal Bilimler Enstitüsü, 2017.

Korlaelçi, Murtaza. "Gazzâlî̉nin İnsan Anlayışı". 900. Vefat Yılında İmam Gazzâlî: Milletlerarası Tartışmalı İlmî Toplantı, 759-86. İstanbul: Marmara Üniversitesi İlahiyat Fakültesi Vakfı Yayınları, 2012.

Necrânî, Takıyyüddîn Muhtâr b. Mahmûd. el-Kâmil fi'l-istiksâ fi mâ beleganâ min kelâmi'l-kudemâ, thk. es-Seyyid Muhammed eş-Şâhid. Kahire: el-Meclisü'l-A 'lâ li’ş-Şuûni'l-İslâmiyye, 1999.

Pezdevî, Ebü'l-Yüsr Muhammed b Muhammed b Hüseyin. Usûlü'd-dîn, thk. Hans Peter Linss. Kahire: el-Mektebetü'l-Ezheriyye li't-Turâs, 2003.

Râzî, Ebû Abdullah Fahreddin Muhammed b. Ömer Fahreddin. el-Erbaîn fì usûli'd-dîn, thk. Ahmed Hicâzî esSekâ. 2 cilt. Kahire: Mektebetü'l-Külliyâti'l-Ezheriyye, 1986.

- el-Mebâhisü'l-meşrikiyye fi ilmi'l-ilâhiyyât ve't-tabîi iyyât, thk. Muhammed Mu'tasım el-Bağdâdî. 2 cilt. Beyrut: Dâru'l-Kitâbi'l-Arabî, 1990.

. el-Metâlibü'l-âliyye mine'l-ilmi'l-ilâhî, nşr. Ahmed Hicâzî es-Sekkâ. 9 c. Beyrut: Dâru'l-Kitâbi'l-Arabî, 1987. 
-_- Muhassalu efkâri'l-mütekaddimîn ve'l-müteahhirîn mine'l-ulemâ, nşr. Taha Abdürrauf Sa'd. Kahire, t.y. . Nihâyetü'l-ukûl, thk. Saîd Fûde. Beyrut: Dâru'z-Zehâir, 2015.

Semerkandî, Şemsüddin. es-Sahâifü'l-ilâhiyye, thk. Ahmed Abdurrahman Şerif. Kuveyt: Mektebetü'l-Felâh, 1985.

- - IIImü'l-âfâk ve'l-enfüs: Âlem ve İnsan, thk. Yusuf Okşar ve İsmail Yürük. İstanbul: Türkiye Yazma Eserler Kurumu Başkanlığı Yayınları, 2020.

Shihadeh, Ayman. "Classical Ash'arī Anthropology: Body, Life and Spirit". The Muslim World 102, sy 3-4 (Ekim 2012): 433-77.

Sühreverdî, Şihâbüddîn. "Hikmetü'l-işrâk". Mecmû̀a-l Musannefât-l Şeyh-i İ̧̧râk, nşr. Henri Corbin. C. 2. Tahran: Pejûheşgâh-1 Ulûm-1 İnsanî ve Motâleât-1 Ferhengî, 1993.

Teftâzânî, Sa'düddin Mes'ûd b. Ömer b. Abdillah el-Herevî. “Makâsıd”. Şerhu'l-Makâsıld içinde. İstanbul: Matbaa-i Muharrem Efendi, 1305.

-_- Şerhu'l-Akâidi'n-Nesefiyye, nşr. Ahmed Hicâzî es-Sekâ. Kahire: Mektebetü'l-Külliyâti'l-Ezheriyye, 1988.

-_—. Şerhu'l-Makâsıd. 2 cilt. İstanbul: Matbaa-i Muharrem Efendi, 1305.

-_—. Tehzîbu'l-mantık ve'l-kelâm, nşr. Abdülkadir Kürdî. Kahire: Matbaatü’s-Saade, 1912.

Tûsî, Ebû Ca 'fer Nasîrüddin Muhammed b. Muhammed. Tecrîdü’l-akâid, thk. Abbas Muhammed Hasan Süleyman. İskenderiye: Dâru'l-Ma'rifetü'l-Câmiiyye, 1996.

———. Telhîsü'l-Muhassal. Beyrut: Dâru'l-Edvâ', 1985.

Türker, Ömer. "Kelâm Geleneğinde Adudüddin el-Îcî: Kelâmın Bilimsel Kimliği Sorunu”. İslâm İlim ve Düşünce Geleneğinde Adudüddin el-Î́cî, 299-337. İstanbul: İSAM Yayınları, 2017.

___. "Kelam ve Felsefe Geleneklerinin Kesişim Noktasında Seyyid Şerif Cürcânî”. İslâm Düşüncesinde Süreklilik ve Değişim: Seyyid Şerif Cürcânî Örneği, ed. M. Cüneyt Kaya, 1-61. İstanbul: Klasik Yayınları, 2015. "Nefis". DİA, XXXII:529-31.

Üçer, İbrahim Halil. İbn Sînâ Felsefesinde Suret, Cevher ve Varlık. İstanbul: Klasik Yayınları, 2017. 